\title{
Phycocyanin Monitoring in Some Spanish Water Bodies with Sentinel-2 Imagery
}

\author{
Rebeca Pérez-González $\left.{ }^{1} \mathbb{(}\right)$, Xavier Sòria-Perpinyà ${ }^{2}{ }^{\mathbb{D}}$, Juan Miguel Soria ${ }^{1} \mathbb{(}$, Jesús Delegido ${ }^{2}$, \\ Patricia Urrego ${ }^{2}{ }^{\infty}$, María D. Sendra ${ }^{1}$, Antonio Ruíz-Verdú ${ }^{2}$, Eduardo Vicente ${ }^{1, *}$ and José Moreno ${ }^{2}$ \\ 1 Cavanilles Institute of Biodiversity and Evolutionary Biology (ICBiBE), Universitat de València, \\ 46980 Valencia, Spain; repegon@alumni.uv.es (R.P.-G.); juan.soria@uv.es (J.M.S.); \\ maria.d.sendra@uv.es (M.D.S.) \\ 2 Image Processing Laboratory (IPL), Universitat de València, 46980 Valencia, Spain; \\ javier.soria-perpina@uv.es (X.S.-P.); jesus.delegido@uv.es (J.D.); patricia.urrego@uv.es (P.U.); \\ antonio.ruiz@uv.es (A.R.-V.); jose.moreno@uv.es (J.M.) \\ * Correspondence: eduardo.vicente@uv.es
}

Citation: Pérez-González, R.; Sòria-Perpinyà, X.; Soria, J.M.; Delegido, J.; Urrego, P.; Sendra, M.D.; Ruíz-Verdú, A.; Vicente, E.; Moreno, J. Phycocyanin Monitoring in Some Spanish Water Bodies with Sentinel-2 Imagery. Water 2021, 13, 2866. https://doi.org/10.3390/w13202866

Academic Editor: Thomas Meixner

Received: 15 September 2021

Accepted: 7 October 2021

Published: 14 October 2021

Publisher's Note: MDPI stays neutral with regard to jurisdictional claims in published maps and institutional affiliations.

Copyright: (c) 2021 by the authors. Licensee MDPI, Basel, Switzerland. This article is an open access article distributed under the terms and conditions of the Creative Commons Attribution (CC BY) license (https:/ / creativecommons.org/licenses/by/ $4.0 /)$.

\begin{abstract}
Remote sensing is an appropriate tool for water management. It allows the study of some of the main sources of pollution, such as cyanobacterial harmful algal blooms. These species are increasing due to eutrophication and the adverse effects of climate change. This leads to water quality loss, which has a major impact on the environment, including human water supplies, which consequently require more expensive purification processes. The application of satellite remote sensing images as bio-optical tools is an effective way to monitor and control phycocyanin concentrations, which indicate the presence of cyanobacteria. For this study, 90 geo-referenced phycocyanin measurements were performed in situ, using a Turner C3 Submersible Fluorometer and a laboratory spectrofluorometer, both calibrated with phycocyanin standard, in water bodies of the Iberian Peninsula. These samples were synchronized with Sentinel-2 satellite orbit. The images were processed using Sentinel Application Program software and corrected with the Case 2 Regional Coast color-extended atmospheric correction tool. To produce algorithms that would help to obtain the phycocyanin concentration from the reflectance measured by the multispectral instrument sensor of the satellite, the following band combinations were tested, among others: band $665 \mathrm{~nm}$, band $705 \mathrm{~nm}$, and band $740 \mathrm{~nm}$. The samples were equally divided: half were used for the algorithm's calibration, and the other half for its validation. With the best adjustment, the algorithm was made more robust and accurate through a recalculation, obtaining a determination coefficient of 0.7 , a Root Mean Square Error of $8.1 \mu \mathrm{g} \mathrm{L}-1$, and a Relative Root Mean Square Error of 19\%. In several reservoirs, we observed alarming phycocyanin concentrations that may trigger many environmental health problems, as established by the World Health Organization. Remote sensing provides a rapid monitoring method for the temporal and spatial distribution of these cyanobacteria blooms to ensure good preventive management and control, in order to improve the environmental quality of inland waters.
\end{abstract}

Keywords: remote sensing; Sentinel-2; phycocyanin; cyanobacterial harmful blooms; cyanotoxins

\section{Introduction}

For populations and ecosystems, water is the most important and necessary natural resource. The massive increase in population in the last 70 years has led to increased demand for water and pressure on aquatic ecosystems, which in turn has led to the construction of reservoirs to ensure water and energy supplies [1]. The number of hydraulic infrastructures combined with sparse ecological monitoring plans has triggered a series of problems that are difficult to manage. One of these problems is the increase of cyanobacteria blooms [2]. In many reservoirs, they exceed the limits set by the World Health Organization [3], which means an increase in toxicity and a risk to the environment and human health. All this is accompanied by an increase in eutrophication, the loss or increase of sediment input, 
and an increase in invasive species, leading to major environmental problems, which are exacerbated mainly by the effects of climate change on the Earth [4].

Since the adoption of the Water Framework Directive (WFD) [5], the European Union has tightened regulations in order to improve the management of inland waters. Better management of water resources and water quality in water bodies is promoted through the implementation of the proposals set out in the WFD. The aim is to achieve a common strategy for the whole of Europe in relation to hydrological planning, including reservoirs, taking into account aspects such as wastewater treatment, public awareness of water use, and the regulation of water supply systems. One of the most important aspects in relation to the WFD is the importance of the ecological status of water bodies along with their chemical status, a concept that has been established as an ecological potential for heavily modified water bodies such as reservoirs. Cyanobacteria play a fundamental role in the assessment of the ecological status of water bodies, as their proportions, especially toxic ones, are used together with other variables, such as chlorophyll- $a$ concentration (Chl-a), transparency, or total phosphorus, to assess the ecological status of water bodies [6].

There are more than 1200 reservoirs in Spain. It is necessary to assess the risks present in these reservoirs and the resulting consequences for the environment and for human beings, since their waters are mainly used for the irrigation of agricultural land and the supply of drinking water, as all major Spanish cities are supplied by surface waters regulated by one or more reservoirs, according to Executive Order No. 817/2015. The water from reservoirs must be treated in drinking water treatment plants before consumption to avoid problems with the security of supply. However, the increase in nutrient levels is too high for lentic waters. Remote sensing plays a very important role in all the studies that need to be carried out to improve the management of water supplies because satellite sensors can be used to observe and estimate the concentrations of various variables, such as Chl-a, suspended solids, water transparency, and phycocyanin (PC), to identify and assess risks and existing problems.

Cyanobacteria are microscopic prokaryotic organisms that contain photosynthetic pigments typical of eukaryotic algae and plants, such as Chl-a and phycobilins, which give them their typical blue-green color [6]. They are estimated to have originated 3.6 billion years ago and to have contributed to the formation of the present atmosphere through oxygenic photosynthesis. Their physiology has evolved little since their emergence. They form a phylum of bacteria with unique ecological characteristics, which makes their classification difficult in many cases. Two different taxonomic classification methods are used: botanical classification and microbiological nomenclature [7]. They are organisms with a high tolerance of sudden environmental changes, which is important for the functioning of aquatic ecosystems [8].

Cyanobacteria are primary producers as they serve as food for zooplankton and some bacteria, thus maintaining the trophic webs of aquatic ecosystems [9]. They occur in different types of habitats, both terrestrial and aquatic, although they are more abundant and significant in aquatic environments. In aquatic environments, they are a fundamental component of food webs, including in marine, brackish and freshwater environments, where blooms or mass blooms may occur [10]. In terrestrial environments, they are found in soils, deserts, tree bark, and symbionts.

Cyanobacteria play an important role in various biogeochemical cycles, such as carbon and nitrogen cycles, with elements being fixed by phytoplankton. In the case of carbon, fixation by phytoplankton leads to a decrease in $\mathrm{CO}_{2}$ concentration at the sea surface, acts as a $\mathrm{CO}_{2}$ sink, and leads to an increase in ocean $\mathrm{pH}$ [8]. The ability to fix carbon depends largely on the availability of macronutrients and the changes that can occur in the Redfield Ratio C:N:P (106:16:1) [11]. When phytoplankton consume too much carbon, as occurs during the development of phytoplankton blooms, the $\mathrm{C}: \mathrm{N}$ ratio changes and can lead to the temporary release and accumulation of carbon-rich dissolved organic matter [12]. The ratio and availability of these nutrients can be altered by the massive artificial input of nutrients, nitrogen and phosphorus into water bodies, resulting in their eutrophication. 
Some species of cyanobacteria contain heterocysts, through which they are able to fix atmospheric $\mathrm{N}$ more efficiently. Therefore, when eutrophy occurs due to excess nutrients, cyanobacteria are able to grow when there is excess phosphorus and nitrogen becomes limited; eventually, they obtain it directly from atmosphere, which makes them colonizers of phosphorous-rich environments [13].

Cyanobacteria require phosphorus and nitrogen dissolved in water to grow and reproduce. In many cases, low concentrations of these nutrients control the growth of cyanobacteria and all phytoplankton. However, human activities can cause excessive supply, triggering the uncontrolled growth of cyanobacteria and resulting in large blooms [14]. These blooms turn the water turbid with an emerald green hue that limits light penetration, thus reducing the photosynthetic capacity of the species found in deeper areas and therefore generating oxygen shortages that can turn the affected areas hypoxic or anoxic [10]. Another major problem in the occurrence of blooms is cyanotoxins. Many taxa of cyanobacteria present secondary metabolites, which generate a wide range of toxins, known as cyanotoxins [15].

Phycocyanin, the majority pigment of cyanobacteria, is a phycobiliprotein pigment that is able to capture light. Along with allophycocyanin and phycoerythrin, it is considered an accessory pigment of chlorophyll [16]; it is water-soluble so it cannot exist inside membranes, unlike carotenoids. PC is blue in color, capable of absorbing orange and red light at a wavelength of about $620 \mathrm{~nm}$, and emits fluorescence at about $650 \mathrm{~nm}$. It should be noted that allophycocyanin absorbs and emits a longer wavelength than PC, $650 \mathrm{~nm}$ and $660 \mathrm{~nm}$, respectively [17].

The assessment of the impact of cyanobacteria on drinking waters can be performed by measuring PC, since the fluorescence detection of PC pigment in freshwaters is a good tool to determine cyanobacterial biomass, or the cyanobacterial blooms mentioned above [18]. In fresh waters, the only microorganisms that produce significant amounts of PC are cyanobacteria and their derivative, allophycocyanin, which is of great ecological importance as it indicates cyanobacterial blooms. In many cases, the concentration of chlorophyll-a is used to obtain the number of cyanobacteria, but it is not an ideal measure because it is present in a large number of phytoplankton groups [19]. The World Health Organization (WHO) established guidelines for drinking water quality that have been updated over the years [3]. These guidelines establish the standards for drinking water, which not only require water management and treatment, but also prior planning and continuous monitoring. The guidelines do not necessarily have to be the same for all the places on the planet, since each country or region adapts them according to its environmental conditions and political and economic conditions. That is why there is no consensus, and each country adopts the measures it considers appropriate within the framework and recommendations pre-established by the WHO, agreed in 1999 in the so-called Stockholm Framework, for future guidelines for drinking water, wastewater, and recreational water. These incorporate risk assessment, risk management options, and exposure control elements in a single framework containing quality objectives.

There are different pathogens in water, usually microbial, that can influence water quality and are treated in order to make water safe for human consumption. To eliminate these pathogenic microorganisms, disinfection is necessary. This is usually performed with chemical substances, mainly chlorine and fluorine compounds, although it should be noted that the WHO established that disinfection with chlorine does not exempt the water from being contaminated, since chlorine is not able to eliminate all the harmful microorganisms that may be present, such as protozoa (Cryptosporidium) and some viruses, and does not eliminate cyanotoxins.

Water quality can be monitored by remote sensing, a tool that allows us to obtain data from the Earth's surface from sensors carried by satellites. The continuous electromagnetic interaction between the Earth's surface and the sensor generates a series of data that must be subsequently processed to obtain information that is of interest and interpretable. Since the beginning of the European Copernicus program, in 2014, environmental changes have 
been studied. Among these environmental changes, the study of water quality by remote sensing has been highly developed, especially in the development of studies of the presence of unicellular algae, the concentration of which is directly proportional to that of their most frequent photosynthetic pigments, such as Chl-a, which is present in all photosynthetic organisms, and PC, which is present in cyanobacteria [18].

Included in this program are the Sentinel missions, whose function is mainly based on transforming data obtained by satellites, remotely, into information through processing and analysis; the data are later integrated with other sources and subsequently validated [20]. Sentinel missions refer to each of the satellites sent into space over the years. Sentinel-2A (S2A) in 2015, together with its companion, Sentinel-2B (S2B), which was launched in 2017, are part of a high resolution, multispectral mission in polar orbit that allow the study and monitoring of the Earth's surface, which is mainly focused on monitoring natural disasters and land use areas, as well as land surface isolation for territorial planning and forest management [21]. It is also useful for small water bodies due to its spatial resolution.

The novelty of this study consists in observing the presence of PC using Sentinel-2 imagery, reviewing the most appropriate equations in published papers for image processing in the reservoirs considered, and thus selecting the most suitable equation for a study of the presence of PC in Spanish reservoirs that can be applied elsewhere. Thus, the objectives of the present work are to apply remote sensing as a tool to quantify the concentration of PC using satellite sensors as a proxy for the abundance of cyanobacteria for the monitoring, control, and management of inland waters. To this end, specific fluorescence from PC will be measured as a function of cyanobacterial biomass; a model relating in situ phycocyanin concentrations, and the reflectance measured by the Sentinel-2 Multispectral Instrument sensor (MSI) will be calibrated. Finally, the model for estimating PC concentration will be validated to obtain thematic maps of concentrations and alert levels in some reservoirs as a case of study.

\section{Materials and Methods}

\subsection{Study Site}

For this work, data were collected from 2016 to 2020 from 30 different reservoirs in three basins of the Iberian Peninsula: Ebro, Jucar and Tagus (Spain). Their spatial distribution is presented in Figure 1, including one reservoir in the Tagus basin, nine in the Jucar and twenty in the Ebro, whose characteristics are described in Table A1. They stand out because they are all have a capacity greater than $10 \mathrm{hm}^{3}$.

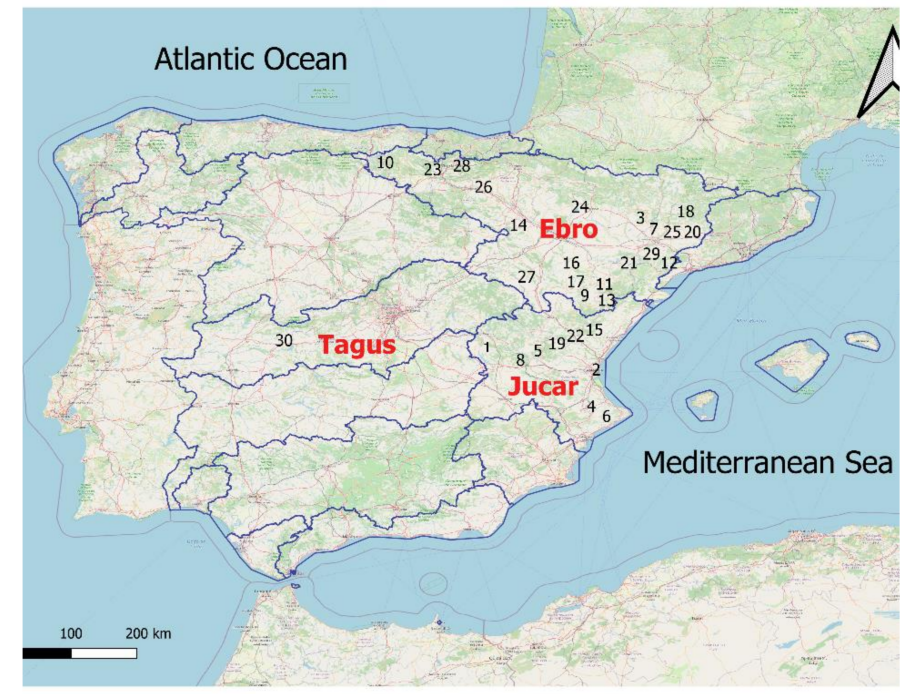

Figure 1. Map of watersheds of Spain showing the location of the reservoirs studied, the number of which coincides with that used in Table A1 of the Appendix A. 
The need for reservoirs in Spain is due to the irregularity of rainfall. For this reason, it is necessary to have special control over the reservoirs and rationalize the water they supply to avoid future problems in periods of drought.

\subsection{Sampling Methods}

In situ sampling allows us to know the concentrations of solids, organic matter, Chl-a and PC. For in situ sampling, we used a boat to surf the reservoir and go to the sampling sites, which were usually in the same site field. Prior to sampling, it was necessary to consult the weather forecast, since the satellite image is not affected by cloud cover and the wind speed does not exceed $10 \mathrm{~km} \mathrm{~h}^{-1}$.

A GPS was used to reach the sampling point. Once there, the anchor and the buoy were pulled to affix the boat and make the corresponding measurements. The transparency was measured by means of the Secchi disk depth (SDD), submerging a disc of $20 \mathrm{~cm}$ of diameter until it reaches a depth at which it is not visible. The in situ determination of PC and Chl-a was performed using a Turner Design submersible C3 field fluorometer calibrated with Spirulina Standard 40\% purity (Sigma-Aldrich CAS 11016-15-2, Sant Louis, MO, USA). This fluorimeter works by means of a sequence of excitation LEDs that ensure that the data measurement is independent of the environmental lighting. A vertical profile of measurements was produced descending to the depth of the SDD, recording every four seconds the depth value and the fluorometric measurements.

In the Ebro, the integrated samples were taken until the SDD, using a ballasted PVC tube, preserved in darkness and refrigerated. The PC concentrations were also analyzed in the laboratory using the Hitachi FL-7000 spectrofluorometer so that the PC concentration values were obtained by measuring the fluorescence intensity with respect to the PC concentration, for which the Spirulina Standard was also used.

The PC adjustment (Figure 2) was PC $=0.3253 \times \mathrm{RF}$, calculated from the PC standard concentration and raw fluorescence (RF). From fitting the equation developed, the values for each sample were obtained.

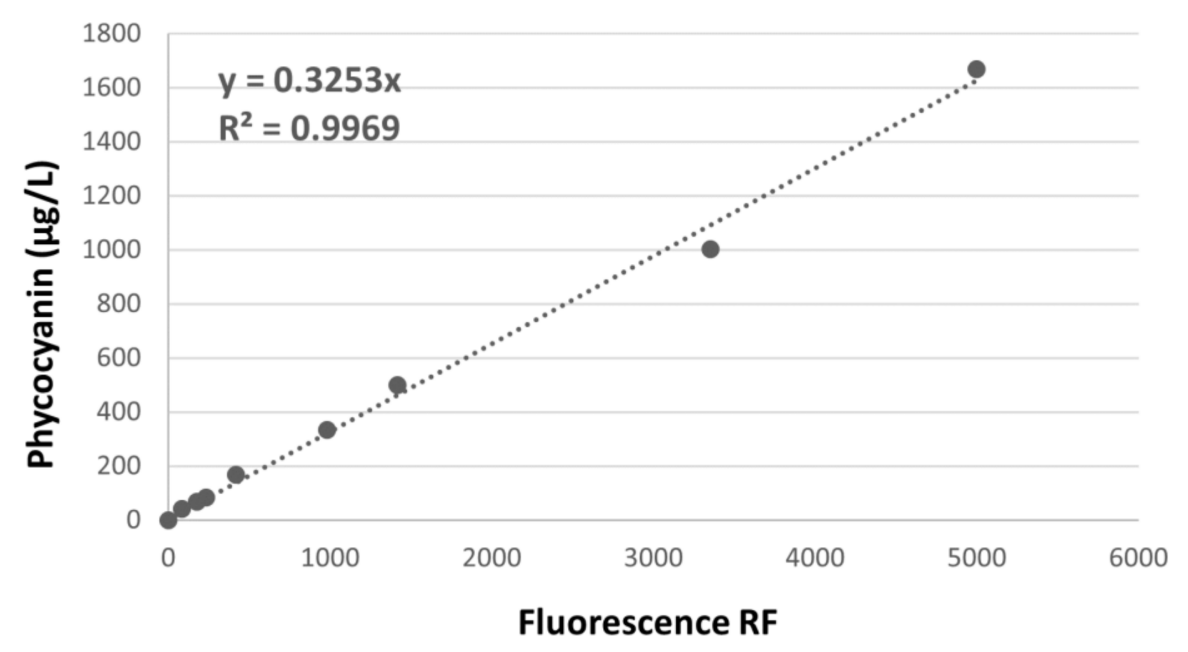

Figure 2. Calibration adjustment between raw fluorescence units (RF) and standard phycocyanin concentration for Hitachi FL-7000 spectrofluorometer.

The Chl-a was measured in the laboratory using the spectrophotometric method. The samples were filtered through 0.4-0.6 $\mu \mathrm{m}$ GF/F glass fiber filters, extracted using standard methods [22] and calculated with Jeffrey and Humphrey methods [23].

\subsection{Image Processing}

The $\mathrm{S} 2$ satellite includes 13 bands of different spatial resolutions: $10 \mathrm{~m}, 20 \mathrm{~m}$ and $60 \mathrm{~m}$ (Table 1). The S2 images were downloaded at the same time as the field data acquisition, level L1C (without atmospheric correction), from two different servers, mainly from the 
ESA Open Access Hub server, which is a free ESA tool that allows the download of images from different satellites for further processing. The images not available on the ESA server were downloaded from Earth Explorer, a North American server of the U.S. Geological Survey.

Table 1. Sentinel-2 spectral bands: Visible (VIS), Near-infrared (NIR) and Short-Infrared (SWIR), according to ESA [21].

\begin{tabular}{|c|c|c|c|c|c|}
\hline \multirow{2}{*}{\multicolumn{2}{|c|}{ Band }} & \multicolumn{2}{|c|}{ Wavelength (nm) } & \multirow{2}{*}{$\begin{array}{c}\text { Spatial } \\
\text { Resolution (m) }\end{array}$} & \multirow{2}{*}{ Objective } \\
\hline & & Central & Wide & & \\
\hline B1 & \multirow{4}{*}{$\stackrel{\infty}{>}$} & 443 & 20 & 60 & \multirow{4}{*}{$\begin{array}{c}\text { Aerosol Correction } \\
\text { Aerosol Correction, Blue Band } \\
\text { Measure } \\
\text { Green Band Measure } \\
\text { Red Band Measure }\end{array}$} \\
\hline B2 & & 490 & 65 & 10 & \\
\hline B3 & & 560 & 35 & 10 & \\
\hline B4 & & 665 & 30 & 10 & \\
\hline B5 & \multirow{6}{*}{ 当 } & 705 & 15 & 20 & \multirow{6}{*}{$\begin{array}{c}\text { Red Edge } 1 \text { Band Measure } \\
\text { Red Edge } 2 \text { Band Measure } \\
\text { Red Edge } 3 \text { Band Measure } \\
\text { Water Vapor Correction, Near } \\
\text { Infrared Band } \\
\text { Water Vapor Correction, Near } \\
\text { Infrared Band } \\
\text { Water Vapor Correction, Near } \\
\text { Infrared Band }\end{array}$} \\
\hline B6 & & 740 & 15 & 20 & \\
\hline B7 & & 783 & 20 & 20 & \\
\hline B8 & & 842 & 115 & 10 & \\
\hline B8a & & 865 & 20 & 20 & \\
\hline B9 & & 945 & 20 & 60 & \\
\hline B10 & \multirow{3}{*}{ 歺 } & 1380 & 20 & 60 & \multirow{3}{*}{$\begin{array}{l}\text { Cirrus Detection, Infrared Band } \\
\text { Infrared Band } \\
\text { Aerosol Correction, Infrared Band }\end{array}$} \\
\hline B11 & & 1610 & 90 & 20 & \\
\hline B12 & & 2190 & 180 & 20 & \\
\hline
\end{tabular}

Once downloaded, the images were processed with the Sentinel Application Platform (SNAP, Brockmann Consult Gmbh, Hamburg, Germany), an application developed for ESA. The SNAP application is a free resource offered to process and analyze satellite images together with the tools of the Sentinel and other satellites. The software has several atmospheric correction methods; the most developed for aquatic subjects is Case 2 Regional Coast Colour (C2RCC), adapted for S2 and used for Case-1 waters, which are not as turbulent as marine waters. On the other hand, there is the Case-2 Extreme Cases (C2X) process, a version developed for turbid waters, such as continental Case-2 waters [23]. These two atmospheric correction methods are based on reflectance and radiance data obtained through simulations in radiative transfer models, which are responsible for performing the inversion through neural networks [24]. In this case, the C2X processor was selected for the atmospheric correction, which is the best process for inland waters due to the amount of organic matter and phytoplankton they contain. In addition, SNAP has a large number of built-in algorithms with different biophysical variables, which allows the development of new algorithms [25], which in this case were used to evaluate aquatic aspects related to PC.

The downloaded images were resampled to $20 \mathrm{~m}$. This was because for further processing, it was necessary for all the bands to have the same spatial resolution. Once resampled, the area of interest was cropped to facilitate the atmospheric correction process.

This process also resulted in automatic products that presented information on water quality through the values of maximum transparency, Chl-a concentration, and suspended solids, among others. Once the atmospheric correction was performed, the values of the pixel bands were extracted from a $3 \times 3$ window centered in the coordinates of each sample point. For the nine values of the 13 bands, the mean and standard deviation were calculated; the values with a difference greater or less than the standard deviation with respect to the mean were eliminated. With the remaining values, a new mean and standard deviation were calculated to obtain more adjusted data. 
The Band Maths tool was used to obtain the thematic maps of PC, a biophysical variable not included in SNAP. This tool makes it possible to apply the equation from the best model obtained once the calibration and validation process is complete.

\subsection{Calibration}

Once all the data were compiled, we proceeded to compile the database by gathering all the available information from the PC and reflectance data. With all these data, we calculated indices that related the different reflectance bands with the PC in order to establish the one that best fitted our study (Table 2).

Table 2. Reference equations for the study and corresponding values. N: number of data; $\mathrm{R}^{2}$ : Pearson determination coefficient; RMSE: Root mean square error.

\begin{tabular}{cccccccc}
\hline Reference & Sensor & $\begin{array}{c}\text { Atmospheric } \\
\text { Correction }\end{array}$ & Bands Relation & N & $\mathbf{R}^{2}$ & RMSE & Data Range \\
\hline$[25]$ & S2-MSI & $\begin{array}{c}\text { In situ } \\
\text { Reflectance } \\
\text { In situ }\end{array}$ & R740-R665 & 29 & 0.70 & 4.82 & $0-23 \mathrm{RFU}$ \\
{$[25]$} & S3-OLCI & $\begin{array}{c}\text { Reflectance } \\
\text { Sen2cor }\end{array}$ & R707/R679 & 9 & 0.86 & 1.45 & $0-23 \mathrm{RFU}$ \\
{$[26]$} & S2-MSI & R740/R665 & 21 & 0.84 & 141 & $10-1287 \mathrm{mg} / \mathrm{m}^{3}$ \\
{$[27]$} & Dron & R709/R620 & 92 & 0.95 & - & $0.43-13.07 \mathrm{mg} / \mathrm{m}^{3}$ \\
{$[28]$} & S3-OLCI & $\begin{array}{c}\text { In situ } \\
\text { Reflectance }\end{array}$ & $\left(\left(\frac{1}{R 620}-\frac{0.4}{R 560}-\frac{0.6}{R 709}\right) \times R 754\right)$ & 216 & 0.69 & 22.7 & $0.33-317.74 \mathrm{mg} / \mathrm{m}^{3}$ \\
This Study & S2-MSI & C2X & R705-R665 & 45 & - & - & $0.23-364.7 \mathrm{mg} / \mathrm{m}^{3}$ \\
\hline
\end{tabular}

Some of the indices used were based on previous studies. They were modified to adapt to the available S2 bandwidth. A new index was also proposed.

Once the normality of the data was verified, the reflectances were correlated with the PC concentrations and their logarithm, with the band ratio on the abscissa axis and the PC concentration, or its logarithm, on the ordinate axis. To proceed with calibration and validation, all the data from 2016 to 2020 were equally divided into two groups of data with the same range. Finally, with the best ratio, the adjustment was performed using all the data. This procedure helped to better fit the data and to establish valid correlations.

This procedure was performed for all the indices, and the determination coefficients $\left(\mathrm{R}^{2}\right)$ were obtained. The type of regression used varied according to the best fit to our data; in some cases, potential or logarithmic regressions were used when a better fit was observed.

\subsection{Validation}

The calibration of each index provided the equations, which were later used to estimate the PC values to be validated. The validation process was performed for each index to find the one that best fitted our specific case of study.

For the validation, an adjustment was made to relate the estimated PC with the observed PC, obtaining the $\mathrm{R}^{2}$ value. In addition, different errors were calculated: the root mean square error (RMSE) and the relative root mean square error (RRMSE). The statistical processes were calculated with SigmaPlot 14 software.

It should also be noted that this was an iterative process, which allowed us to corroborate the best method for both calibration and validation. We performed a series of tests to find the best algorithm to apply to the case in our study.

Once the validations were completed and we obtained the best retrieval algorithm for PC, we proceeded to elaborate the thematic maps with the classification established by the WHO with respect to PC (Table 3). 
Table 3. Classification according to WHO, with the modifications of density, biovolume, and chlorophyll-a according to [29], and phycocyanin according to [18].

\begin{tabular}{cccccc}
\hline $\begin{array}{c}\text { Drinking } \\
\text { Water }\end{array}$ & Bath Water & $\begin{array}{c}\text { Density } \\
\left(\text { Cell } \mathbf{~ L L}^{-\mathbf{1}}\right)\end{array}$ & $\begin{array}{c}\text { Biovolum } \\
\left(\mathbf{m m}^{\mathbf{3}} \mathbf{L}^{-\mathbf{1}}\right)\end{array}$ & $\begin{array}{c}\text { Chlorophylla } \\
\left(\mu \mathbf{~ L ~}^{-\mathbf{1}}\right)\end{array}$ & $\begin{array}{c}\text { PC } \\
\left(\mu \mathbf{g ~ L}^{-\mathbf{1}}\right)\end{array}$ \\
\hline Surveillance level & 200 & 0.02 & 0.1 & $<0.1$ \\
\hline \multicolumn{2}{c}{ Alert level I } & 2000 & 0.2 & 1.0 & 4 \\
\hline $\begin{array}{c}\text { Guidance } \\
\text { level I }\end{array}$ & 20,000 & 2 & 10 & $90 \pm 2$ \\
\hline Alert level II & $\begin{array}{c}\text { Guidance } \\
\text { level II }\end{array}$ & 100,000 & 10 & 50 & $90 \pm 2$ \\
\hline
\end{tabular}

\section{Results}

After the treatment and processing, a total of 90 data along with high quality images were used in the study. The table of descriptive statistics of the results (Table 4) includes the descriptive statistics of the variables measured in the reservoirs. In some samples, we observed PC values higher than the Chl-a concentration, as is typical of eutrophic systems [26].

Table 4. Descriptive statistical values of chlorophyll-a (Chl-a), Secchi disk depth (SDD), suspended solids (SS), and phycocyanin (PC).

\begin{tabular}{ccccc}
\hline & Chl-a $\left(\mu \mathbf{g ~ L}^{-\mathbf{1}}\right)$ & SDD $(\mathbf{m})$ & SS $\left(\mathbf{m g ~ L}^{-\mathbf{1}}\right)$ & PC $\left(\boldsymbol{\mu g ~ \mathbf { ~ L } ^ { - 1 } )}\right.$ \\
\hline Maximum & 91.92 & 9.10 & 48.56 & 364.70 \\
Minimum & 0.61 & 0.35 & 0.30 & 0.23 \\
Mean & 9.82 & 3.36 & 6.07 & 37.56 \\
St. Deviation & 16.61 & 2.23 & 10.77 & 80.18 \\
\hline
\end{tabular}

Descriptive statistics were also established, including a comparison between the concentrations of PC and Chl-a in the studied reservoirs of the Jucar and Ebro watersheds (Figure 3), where it has been verified by means of a t-test that the difference was not statistically significant. Even so, the values of PC in the Jucar basin were much higher than those of Ebro. The results suggested a difference between the Ebro and the Jucar, with much higher concentrations in the reservoirs belonging to the Jucar basin than to those of the Ebro, as well as a correlation between PC and Chl-a concentrations.

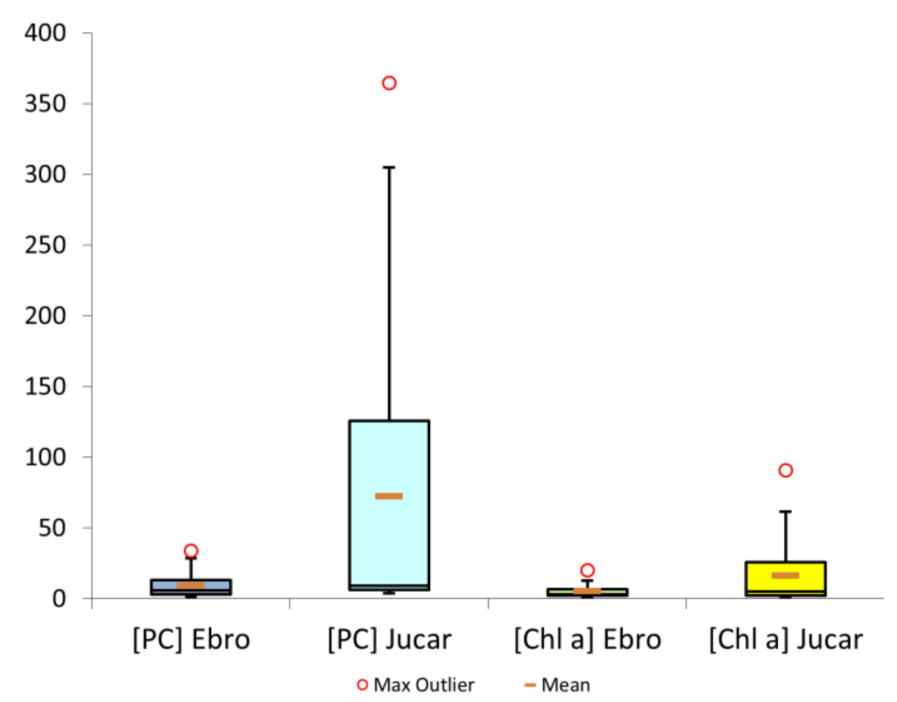

Figure 3. Comparison between PC and Chl-a values in Ebro and Jucar basins in $\mu \mathrm{g} \mathrm{L}-1$.

On the other hand, the monitoring and alert level values, classified according to the $\mathrm{WHO}$ [3] for all the reservoirs studied, are presented in Table A2. 


\subsection{Calibration}

As described in the methodology section, six models were calibrated. The iterative fitting process was performed with five band ratios compiled from previous studies, together with another self-developed ratio. Considering the coefficient of determination, the best ratio was the R705/R665 using raw data (Figure 4). The band ratio was based on the algorithms described by $[25,27]$.

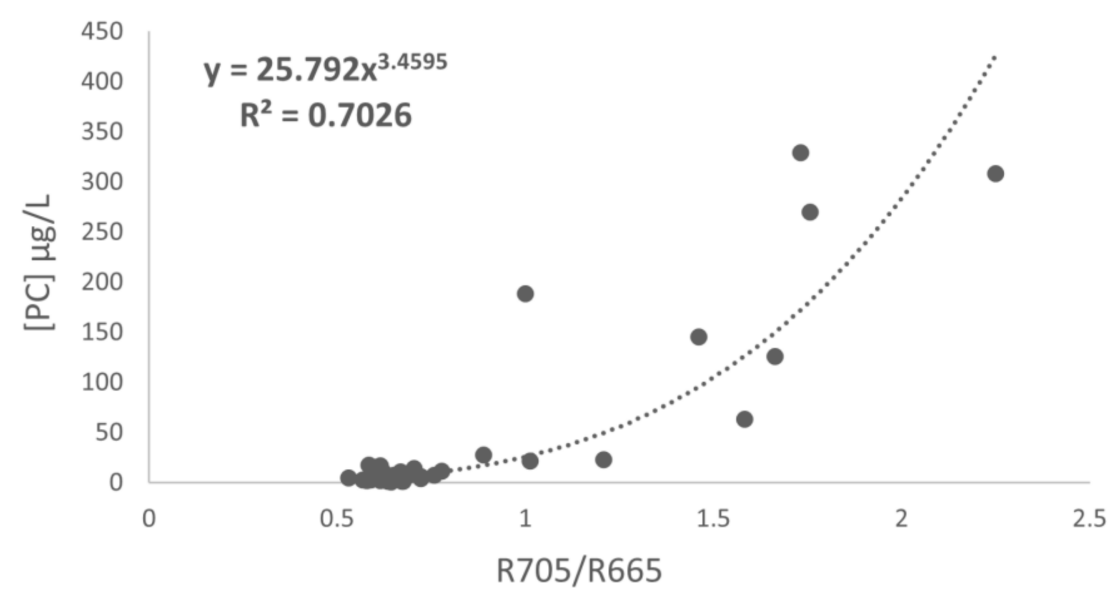

Figure 4. Correlation between the R705/R665 ratio and PC observed in the reservoir.

Table 5 shows the results of the calibration for the six different band relations. A potential or linear fit was performed, depending on which worked best with their respective coefficients of determination using the PC concentration values on the one hand and Ln on the other. As can be seen, the $\mathrm{R}^{2}$ of [28] was the best relationship; the problem was that this relationship estimated a large number of negative values in the validation.

Table 5. Calibration results: fit equations and coefficients of determination.

\begin{tabular}{ccccc}
\hline Band Ratio & PC & R2 & PC Log. & $\mathbf{R}^{\mathbf{2}}$ \\
\hline$[25]$ & $-295.15(\mathrm{R} 740-\mathrm{R} 665)+36.165$ & 0.0007 & $-47.348(R 740-R 665)+1.9091$ & 0.05 \\
{$[25,27]$} & $25.792(\mathrm{R} 705 / \mathrm{R} 665)^{3.4595}$ & 0.70 & $3.1454\left(\frac{R 705}{R 665}\right)-0.2847$ & 0.69 \\
{$[26]$} & $387.84(\mathrm{R} 740 / \mathrm{R} 665)^{2.3932}$ & 0.67 & $5.9764\left(\frac{R 740}{R 665}\right)+0.758$ & 0.64 \\
{$[28]$} & $669.65\left(\left(\frac{1}{R 620}-\frac{0.4}{R 560}-\frac{0.6}{R 709}\right) \times R 754\right)+$ & 0.74 & $11.071\left(\left(\frac{1}{R 620}-\frac{0.4}{R 560}-\frac{0.6}{R 709}\right) \times R 754\right)+$ & 0.59 \\
R705-R665 & $8595.3(R 705-R 665)+38.796$ & 0.64 & $14051.82\left(\frac{R 705}{R 665}\right)-2.3022$ & 0.51 \\
\hline
\end{tabular}

\subsection{Validation}

The best results in the validation process were obtained by the algorithm calculated with the band ratio R705/R665 (Figure 5), because it offered the best level of errors without estimating negative values. The results of all the validations tested are given in Table 6 . 


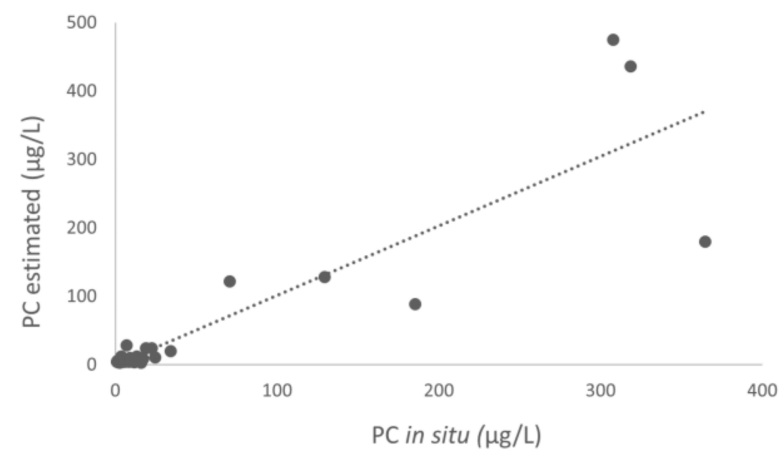

(a)

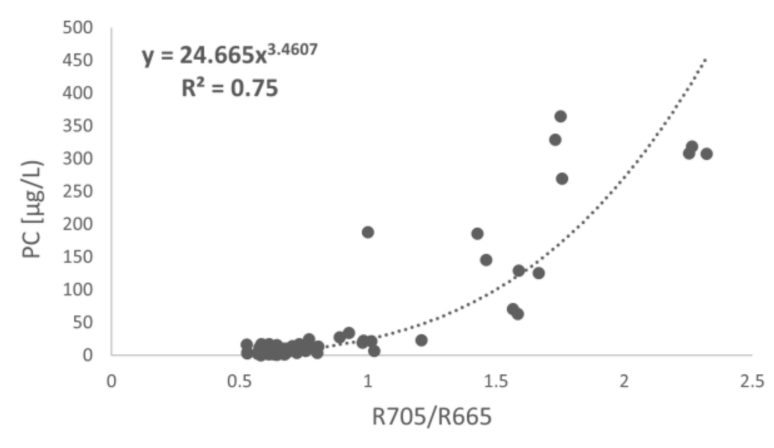

(b)

Figure 5. (a) Validation of R705/R665 algorithm (the dotted line is 1:1 line) and (b) R705/R665 algorithm recalculated with all the data.

Table 6. Validations results.

\begin{tabular}{|c|c|c|c|c|c|}
\hline & Band Ratio & Equation & $\mathbf{R}^{2}$ & $\begin{array}{c}\text { RMSE } \\
\left(\mu \mathrm{g} \mathrm{L}^{-1}\right)\end{array}$ & $\begin{array}{c}\text { RRMSE } \\
(\%)\end{array}$ \\
\hline & R740-R665 & $y=-47.348 x+1.9091$ & 0.02 & 13.42 & 31.22 \\
\hline & R740/R665 & $y=387.84 x^{2.3932}$ & 0.61 & 9.92 & 23.08 \\
\hline & R705/R665 & $y=24.665 x^{3.4607}$ & 0.71 & 8.13 & 18.91 \\
\hline & R705-R665 & $y=8595.3 x+38.796$ & 0.72 & 7.21 & 16.78 \\
\hline$\left(\left(\frac{1}{R 620}-\right)\right.$ & $\left.\left.\frac{0.4}{R 560}-\frac{0.6}{R 709}\right) \times R 754\right)$ & $y=669.65 x+14.808$ & 0.66 & 7.82 & 18.19 \\
\hline
\end{tabular}

The results demonstrated that the best $\mathrm{R}^{2}$ was obtained with the R705-R665 ratio $\left(R^{2}=0.72\right)$, although it estimated negative values. Therefore, the best results were obtained with the R705/R665 ratio, applying the equation $y=24.665 x^{3.4607}$ with an $R^{2}$ of 0.71 , an RMSE of $8.13 \mathrm{mg} / \mathrm{m}^{3}$ and an RRMSE of $18.91 \%$, taking into account all the characteristics of the study and the modification of bands with respect to the initial band ratio established by [27] using a hyperspectral sensor. Finally, Figure $6 \mathrm{~b}$ shows the model with the R705/R665 ratio using all the data of the study.

\subsection{Thematic Maps}

After downloading, the required images were processed with SNAP software, resampled, and cropped. The RGB false color image of the study area was obtained using bands 2, 3 and 4 (Figure 6a). Afterwards, the atmospheric correction was performed (Figure 6b) by applying the $\mathrm{C} 2 \mathrm{X}$ correction.

At the same time, the automatic SNAP products, such as Chl-a and SS, were obtained, to which a color palette was applied and superimposed over the RGB image (Figure $6 c, d$ ). The PC was calculated using SNAP Band Maths tool, which allowed mathematical operations to be performed with the bands. The equation in Figure $5 \mathrm{~b}$ was applied and the gray image was obtained (Figure 6e), the color palette was applied and then superimposed on the initial RGB image (Figure 6f). 


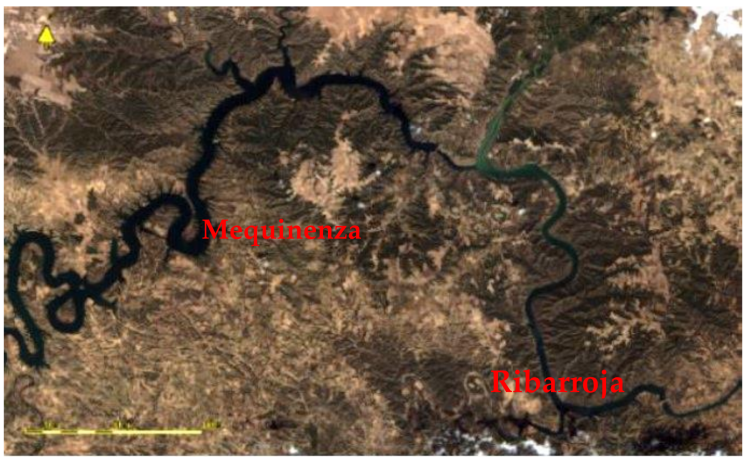

(a) RGB

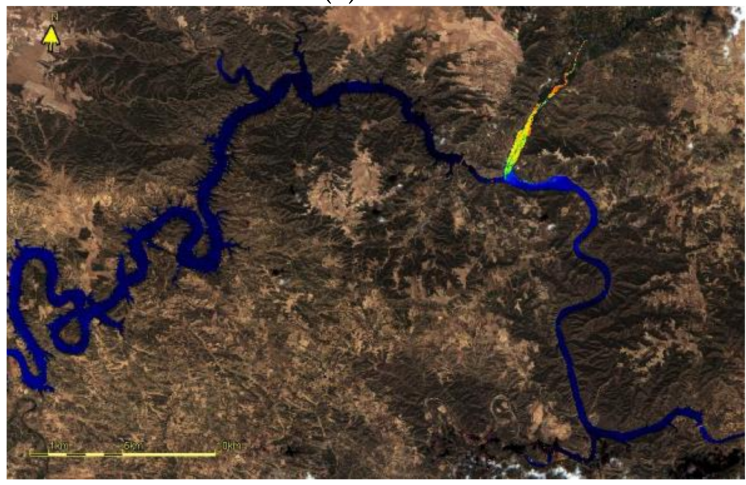

conc_tsm [g m^-3]

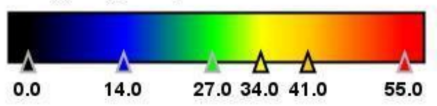

(c) Total suspended materials

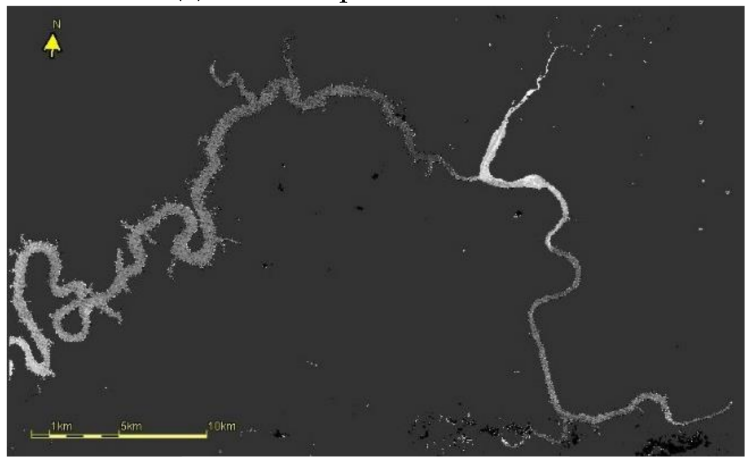

B5_B4 D

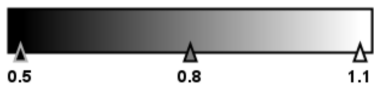

(e) Quotient between R705 and R665

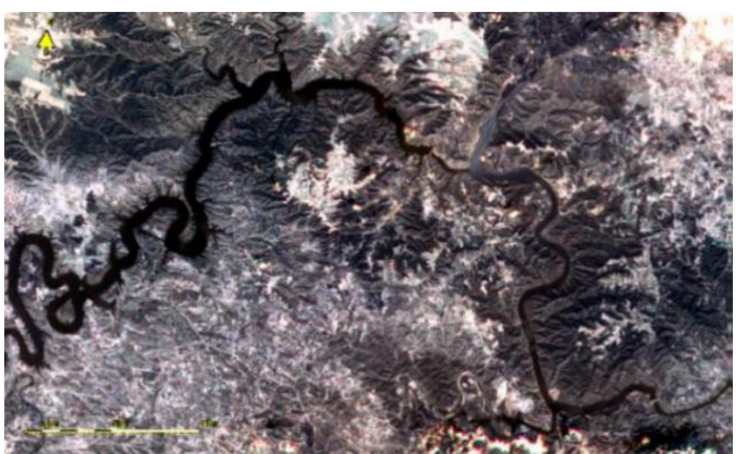

(b) C2RCC-C2X

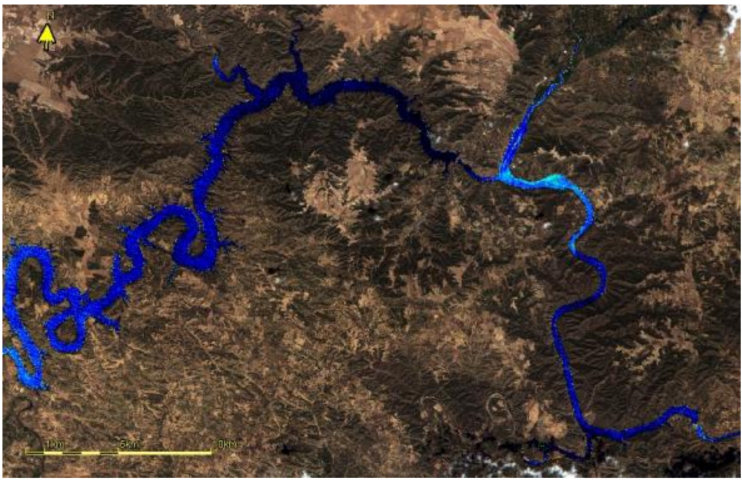

conc_chl $\left[\mathrm{mg} \mathrm{m} \mathrm{m}^{\wedge}-3\right]$

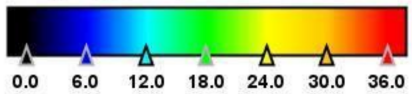

(d) Chlorophyll-a

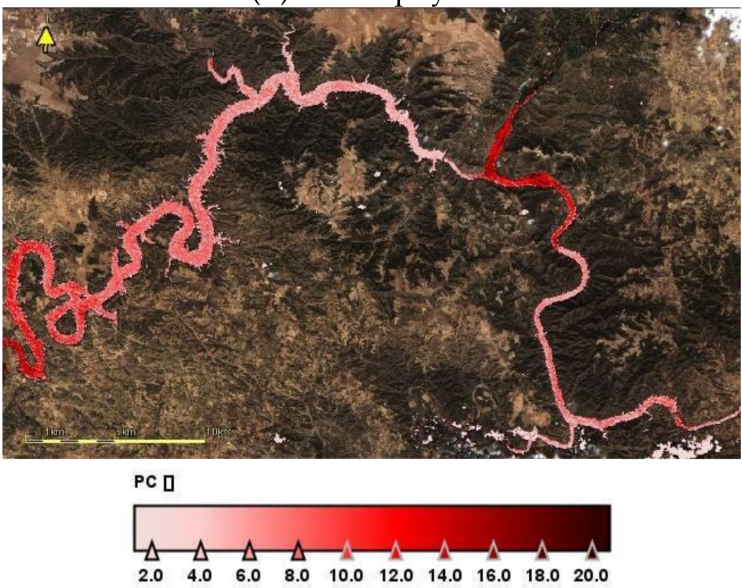

(f) Phycocyanin

Figure 6. Example of thematic maps processing. The image of the lower Ebro in summer 2018: Mequinenza and Ribarroja reservoirs. (a) RGB map; (b) RGB image with C2X atmospheric correction; (c) map of total suspended matter automatic product; (d) map of Chl-a automatic product; (e) map of PC in gray scale applying the R705/R665 algorithm; (f) PC ( $\mu \mathrm{g} / \mathrm{L}$ ) in its corresponding scale.

We selected some images of the reservoirs for consideration in our case of study. The thematic maps of PC concentration and WHO classification are presented in Appendix A, Figures A1-A3. We can view the classification of alert and guideline levels according to the concentrations of PC present in some reservoirs. Some of them exceed the concentration of $100 \mathrm{\mu g} \mathrm{L}^{-1}$, and could lead to serious water quality problems. The water bodies with greater concentrations of PC are the Albufera of Valencia lagoon, Bellus reservoir, and Valdecañas reservoir. Albufera of Valencia is a highly eutrophicated lagoon and, therefore, its PC 
concentrations are higher than in other reservoirs; according to [26], PC concentrations of $1200 \mu \mathrm{g} \mathrm{L}^{-1}$ are reached at certain times of the year, which represents a significant risk related to the proliferation of potential toxic cyanobacteria. In that study, the R740/R665 band ratio was considered the best fitted to the PC trend, and therefore the algorithm derived from this ratio was used in their PC estimation, which obtained a very tight relation between the in situ measurements and the estimated ones. This was applied to Valdecañas reservoir, a reservoir that has been extensively studied over the years due to its concentrations of PC and its associated risk of toxic cyanobacteria. Already in 2004, the toxicity in Tagus reservoirs, including Valdecañas, was really worrying due to microcystins caused by the ineffective treatment of wastewater in Madrid County.

\section{Discussion}

\subsection{Satellite Sensors and Spectral Resolution}

The different indices on which the study was based were adjusted to S2 bands, since the sensor used was not the same in all the previous studies considered. In the case of the work of Kwon et al. [27], the possibility of using S2 or Landsat-8 sensors was mentioned, but they defended the idea that the spectral resolution of these two sensors was too rough. This may affect the performance of algal pigment detection, since with a bandwidth between 60 and $80 \mathrm{~nm}$, it may become difficult to discriminate between absorption features [30]. This is why they proposed the use of drone-type sensors, since they offer a finer spectral resolution compared to satellites. The study conducted by Kwon et al. [27] was carried out in three relatively close areas of the same river, in a short period of time (26 July to 25 October 2018); it is likely that using a smaller range of values would lead to better results in this case, where a coefficient of determination of 0.95 from a total of 92 analyzed data was obtained. On the other hand, in the case of the study by Beck et al. [25], the possibility of finding PC and Chl-a reflectance algorithms that are adaptable to a variety of satellite sensors using simulated data is presented, in order to maximize their use and counteract the results obtained in inland water masses. The results obtained by Beck et al. [25], conducted in an area of $8.9 \mathrm{~km}^{2}$, were varied as they observed that, in the same body of water, some sensors performed better than others.

This methodology is complex, since it involves a much longer and more complicated data collection and processing procedure, and the results may not be conclusive due to the wide variety of sensors used. The validated and best-performing band ratios were R740-R665 and R707/R679, with determination coefficients of 0.7 and 0.86 , respectively. Both relationships were applied in this study, and it was seen how the second relationship could be validated with an $R^{2}$ of 0.702 ; on the other hand, the first relationship did not provide statistically significant results $\left(R^{2}=0.0007\right)$.

A study by Liu et al. [28], performed with Sentinel-3 (S3) and MERIS (Medium Resolution Imaging Spectrometer) also presented considerable difficulties. The bands also had to be adapted for use in the MERIS sensor, since they involved a more complex mathematical development when calculating the number of bands necessary to establish a good algorithm. In our study, a similar procedure was used, separating the data into two equal groups to make calibrations and validations, although Liu et al.'s procedure was performed randomly when selecting the data and therefore did not have the same range.

Another of the studies on which the algorithm development of this work was based, by Sòria-Perpinyà el al. [26], established a relationship with S2 using in situ measurements and a ratio of R740/R665. This relationship provided good results when applied to our data with an $R^{2}$ of 0.67 , but not the best, compared to the other algorithms used.

Many studies use equal groups to establish algorithms, some of which are mentioned above [21]. In order to develop good algorithms that adjust better to the intended results, it is necessary to obtain an error that fits well with the parameters that are considered valid in these types of studies.

The use of S3 is quite recurrent in these types of studies, since its superior spectral resolution allows a much more accurate estimation and, therefore, the development of 
algorithms that are more faithful to reality. Even so, the use of S2 is still common in inland waters because of its superior spatial resolution, but the position and bandwidth of S2 is not optimal for detecting some specific features, such as peaks or depressions caused by water reflectance [31].

\subsection{Problems of Cyanobacteria}

Global human population growth has led to an increase in demand and pressure on continental aquatic ecosystems. To deal with this effect, management and environmental monitoring tools are being developed by the European Union and government agencies to reduce the degradation of ecosystems. One example is the WFD, which is a key tool at the European level for the protection and management of water resources throughout the continent. All of this makes it important to carry out work such as the study presented here, in which, using a long list of data taken from reservoirs, models can be developed that can be used to monitor water bodies and create warning systems [32].

We worked with a wide range of data, which shows the variability of the water bodies sampled. The data in this study were collected from 2016 to 2020, and we are still carrying out fieldwork in order to increase their number and thus create a broader and more robust database.

In Table 4, we can observe the maximum and minimum values of the data range noted for PC, with a maximum of $364.7 \mu \mathrm{g} \mathrm{L}^{-1}$ and a minimum of $0.23 \mu \mathrm{g} \mathrm{L}^{-1}$. On the other hand, as can be seen in Figure 3, where pigments are compared between basins, the widest range for the concentration of PC was obtained in the Jucar basin. It should be noted that for our data, there was a direct, proportional relationship between Chl-a and PC, since the greater the Chl-a, the greater the PC, and vice versa [1], as is the case with suspended solids, since a greater number of Chl-a and PC in reservoirs means that there is more phytoplankton mass and, therefore, the amount of suspended organic matter will be higher. This is linked to eutrophication processes and, therefore, to a decrease in the availability of oxygen in water, generating hypoxic environments in which organisms that are unable to survive die and generate more organic matter, thus increasing its concentration [33]. Chl-a is the major pigment present in all plants and algae, and cyanobacteria, PC, and phycoerythrin are accessory pigments. It is important to note that these accessory pigments are capable of absorbing light at different wavelengths than Chl-a, hence their importance [34].

As mentioned earlier, PC is a proxy for the concentration of cyanobacteria, whose proliferation can lead to toxicity in water. Therefore, it can be used as an effective tool for the monitoring and surveillance of reservoir water quality. This fact has led the WHO [3] to establish a range of concentrations, using tables to apply levels (Table 3). These tables have been modified over the years by different studies to establish the differences between densities and bioaccumulations, as well as Chl-a and PC concentrations, the object of study in this work.

There is a relationship between land use and water quality. Although there are generally strict regulations regarding wastewater treatment, what are not so well developed are the self-purification systems of the reservoirs, which favors all the physicochemical and biological processes that reduce the contribution of organic matter and nutrients $[35,36]$. The WHO and WFD guidelines are very important management tools, since they establish the limit of values for water quality, especially those that affect human consumption, whatever the type (agricultural, domestic, drinking, etc.). In recent years, similar regulations, such as Directive 200/60/EC of the European Parliament and Council [5], have gained in importance due to the increased interest in environmental welfare, although, for example, in the case of this directive, Spain did not meet the limits set in 2015, and requested an extension until 2027.

Cyanobacteria are of great environmental importance, since they are $\mathrm{CO}_{2}$ sinks, but not all of them are beneficial, since there are potentially toxic species and because alterations of aquatic ecosystems can occur [37], which can lead to serious problems in water quality and environmental health. These affect both ecosystems and human beings. For this reason, 
a continuous monitoring of their concentrations tis necessary in order to determine when more exhaustive analysis of the possible presence of toxins in water is required.

There is a clear difference between the reservoirs in the Ebro Basin and those of the Jucar, although in neither case are they at a surveillance level, which is the lowest of the levels established by the $\mathrm{WHO}$ and features the fewest monitoring and requirements. In the case of the Ebro, the reservoirs present levels of PC that are around Alert level I; some are already at Alert level II, although these are few. The maximum PC concentrations are $34.05 \mu \mathrm{g} \mathrm{L}{ }^{-1}$. By comparison, the maximum PC in Jucar reservoirs is $364.7 \mu \mathrm{g} \mathrm{L}^{-1}$, which exceeds all the established limits and could pose a serious problem for the management and treatment of these waters.

The pollution of inland water masses is a serious environmental problem that is becoming more and more accentuated, although there are reservoirs that are not negatively affected, as in the case of those of the Ebro. In the area of the Jucar basin, the effects are beginning to be perceived in a more notorious and serious manner. These phenomena are aggravated by climatic conditions and urban planning, which encompasses both what has already been built and future forecasts for the construction of new residential and industrial areas near the reservoirs. Valdecañas in the Tagus, Bellus and Beniarres in the Jucar basin, and El Val in the Ebro basin are clear examples of this.

Cyanobacterial blooms in reservoirs whose purpose is to supply drinking water can cause serious problems for water quality, from altering its taste and odor to compromising its use as a water supply for human consumption [38]. This necessitates the presence of control and management tools both to prevent it from happening and to mitigate its negative effects, such as eutrophication or toxin production [39]. Over the years, Chl-a concentrations and cyanobacterial cell density have been used to estimate the magnitude of cyanobacterial blooms, although Chl-a is not only present in cyanobacteria but is found in all eukaryotic algae [14]. PC is a parameter closely related to cyanobacterial blooms, which makes it possible to establish criteria, such as the modified WHO criteria (Table 3), to determine PC limit values and, therefore, to obtain a much simpler and more effective parameter for measuring blooms, since, by using the optical properties of $\mathrm{PC}$, it can be used as a spectral response standard to determine the abundance of cyanobacteria [39].

The use of remote sensing as a tool for the detection of cyanobacterial blooms through the detection of PC is also important because of their spectral characteristics. In another study [40], Chl-a and PC concentrations were estimated from hyperspectral images of the Airborne Imaging for Applications Spectrometer (AISA) in a mesoeutrophic reservoir with in situ measurements of both pigments and reflectances. After the subsequent processing of collected data, relationships between both parameters were established to develop algorithms, obtaining a better relationship of PC with the band at $628 \mathrm{~nm}\left(\mathrm{R}^{2}=0.8\right)$. With these results [40], it was possible to establish that the relationship between reflectance at $628 \mathrm{~nm}$ and PC concentration provides an approximation of cyanobacteria concentrations in waters, and that hyperspectral images are therefore a useful tool for authorities to determine water quality.

Studies on the estimation of PC have turned towards remote sensing techniques in recent years. These have evolved from in situ pigment measurement techniques, through laboratory experiments to the quantification of the optical properties of pigments in situ, in the field, and directly from satellite data [41,42]. This work follows this line, offering a new tool for determining PC at a wide range of concentrations, i.e., for bodies of water with very different reflectance spectrums.

\section{Conclusions}

Remote sensing was shown to be a helpful tool for the quantification of PC in water masses and, therefore, a useful tool for the monitoring and surveillance of inland waters. This was demonstrated by the algorithm found for the estimation of this variable from the reflectances of the R705 and R665 bands measured by S2-MSI. 
The best correlation of PC was observed with reflectances obtained with the C2X atmospheric correction, and using the R705/R665 ratio, for which an RMSE $=8.1 \mu \mathrm{g} / \mathrm{L}$ and an RRMSE $=18.9 \%$ were obtained.

Monitoring by satellite sensors has featured in many studies, and this work further reinforces remote sensing as a key tool, in addition to supporting the use of S2, which, despite not having as powerful a spectral resolution as other satellites, such as S3, provides better spatial resolution and robust algorithms with statistically significant correlations across all its products. S3 could serve as a tool to validate algorithms developed with S2 and, therefore, to obtain better results.

The elaboration of thematic maps provides information as to the presence of PC levels, especially the spatial heterogeneity of their distribution, which cannot be seen with point control sampling. It also allows the detection and monitoring of bloom periods, their appearance and subsequent disappearance.

This type of work is important for several reasons. One is that the use of remote sensing tools facilitates its elaboration, as well as reducing costs in terms of resources and allowing monitoring on a global scale, thus reaching areas that are difficult to access. On the other hand, this work shows the importance of monitoring water quality, as the concentration of phytoplankton was monitored for many years in this study. However, a significant increase was observed in cyanobacteria, which has become more important in the last fifteen years and will be even more important in the future in a climate change scenario.

Author Contributions: Conceptualization, J.M. and J.D., R.P.-G., J.M.S., X.S.-P. and A.R.-V. designed the methodology for this work. Field and laboratory works: X.S.-P., M.D.S., P.U. and E.V., R.P.-G. analyzed the data and wrote the paper. J.D., E.V. and J.M.S. supervised the manuscript. Funding acquisition, J.M., J.D. and E.V. Writing-review and editing, all authors. All authors have read and agreed to the published version of the manuscript.

Funding: This research was partially funded by the European Union-ERDF and the Ministry of Science and Innovation and the State Research Agency of Spain under project RTI2018-098651BC51 (FLEXL3L4-Advanced Products L3 and L4 for the FLEX-S3 mission) and partially funded by the GENERALITAT VALENCIANA postdoc research grant (X.S.-P) APOSTD/2020/134, project SEQUARMON (Sentinel quality reservoirs monitoring).

Institutional Review Board Statement: Not applicable.

Informed Consent Statement: Not applicable.

Data Availability Statement: Images are available at ESA Copernicus Hub and Eathexplorer web of United States Geological Survey.

Acknowledgments: The authors would like to thank the field personnel for their collaboration in the sampling work.

Conflicts of Interest: The authors declare no conflict of interest. The funders had no role in the design of the study; in the collection, analyses, or interpretation of data; in the writing of the manuscript, or in the decision to publish the results. 


\section{Appendix A}

Table A1. Some hydrologic characteristics of the studied reservoirs.

\begin{tabular}{|c|c|c|c|c|c|c|c|c|}
\hline & \multirow{2}{*}{ Name } & \multicolumn{2}{|c|}{ Position } & \multirow{2}{*}{$\begin{array}{c}\text { Max Depth } \\
\text { (m) }\end{array}$} & \multirow{2}{*}{$\begin{array}{l}\text { Volume } \\
\left(\times 10^{6} \mathrm{~m}^{3}\right)\end{array}$} & \multirow{2}{*}{$\begin{array}{c}\text { Elevation } \\
\text { (m.a.s.1.) }\end{array}$} & \multirow{2}{*}{$\begin{array}{l}\text { Res. Time } \\
\text { (Year) }\end{array}$} & \multirow{2}{*}{ Climate } \\
\hline & & Lat. & Lon. & & & & & \\
\hline 1 & Alarcón & 39.69 & -2.17 & 71 & 1118 & 806 & 2.15 & Csa \\
\hline 2 & Albufera & 39.34 & -0.35 & 2 & 23 & 1 & 0.15 & Csa \\
\hline 3 & Barasona & 42.14 & 0.33 & 66 & 85 & 448 & 0.24 & Cfa \\
\hline 4 & Bellus & 38.93 & -0.47 & 34 & 69 & 144 & 0.63 & Csa \\
\hline 5 & Benageber & 39.73 & -1.09 & 90 & 221 & 450 & 0.35 & Csb \\
\hline 6 & Beniarres & 38.80 & -0.35 & 53 & 27 & 318 & 1.22 & Csa \\
\hline 7 & Canelles & 42.03 & 0.65 & 150 & 201 & 506 & 1.00 & $\mathrm{Cfb}$ \\
\hline 8 & Contreras & 39.62 & -1.53 & 129 & 384 & 669 & 1.48 & Csa \\
\hline 9 & $\begin{array}{c}\text { Cueva } \\
\text { Foradada }\end{array}$ & 40.97 & -0.69 & 65 & 22 & 580 & 0.65 & Bsk \\
\hline 10 & Ebro & 42.97 & -4.07 & 34 & 540 & 838 & 1.55 & $\mathrm{Cfb}$ \\
\hline 11 & $\begin{array}{c}\text { Estanca de } \\
\text { Alcañiz }\end{array}$ & 41.06 & -0.18 & 15 & 7 & 342 & 0.14 & BSk \\
\hline 12 & Flix & 41.23 & 0.53 & 26 & 11 & 41 & 0.01 & BSk \\
\hline 13 & Gallipuen & 40.87 & -0.41 & 36 & 4 & 694 & 0.71 & $\mathrm{Cfb}$ \\
\hline 14 & La Loteta & 41.82 & -1.32 & 34 & 100 & 288 & 3.51 & BSk \\
\hline 15 & $\begin{array}{c}\text { Maria } \\
\text { Cristina }\end{array}$ & 40.02 & -0.16 & 38 & 18 & 100 & 5.96 & Csa \\
\hline 16 & Mezalocha & 41.42 & -1.07 & 45 & 4 & 473 & 1.17 & Cfa \\
\hline 17 & Moneva & 41.17 & -0.83 & 45 & 8 & 615 & 0.95 & $\mathrm{Cfb}$ \\
\hline 18 & Oliana & 42.12 & 1.30 & 102 & 84 & 519 & 0.08 & Cfa \\
\hline 19 & Regajo & 39.89 & -0.52 & 23 & 6 & 407 & 0.14 & Csa \\
\hline 20 & Rialb & 41.97 & 1.23 & 99 & 402 & 430 & 0.36 & Cfa \\
\hline 21 & Ribarroja & 41.33 & 0.36 & 60 & 207 & 70 & 0.03 & $\mathrm{Csb}$ \\
\hline 22 & Sitjar & 40.01 & -0.23 & 58 & 49 & 160 & 0.37 & Csa \\
\hline 23 & Sobrón & 42.76 & -3.15 & 39 & 20 & 511 & 0.06 & $\mathrm{Cfb}$ \\
\hline 24 & La Sotonera & 42.11 & -0.68 & 31 & 189 & 417 & 0.58 & Cfa \\
\hline 25 & Terradets & 42.05 & 0.88 & 47 & 33 & 372 & 0.04 & Cfa \\
\hline 26 & Tous & 39.13 & -0.65 & 110 & 378 & 135 & 0.28 & Csa \\
\hline 27 & Tranquera & 41.24 & -1.78 & 81 & 84 & 684 & 0.68 & BSk \\
\hline 28 & Urrunaga & 42.98 & -2.65 & 31 & 72 & 547 & 0.31 & $\mathrm{Csb}$ \\
\hline 29 & Utchesa & 41.50 & 0.53 & 5 & 4 & 147 & 0.31 & BSk \\
\hline 30 & Valdecañas & 39.82 & -5.42 & 98 & 1446 & 315 & 0.36 & $\mathrm{Csb}$ \\
\hline
\end{tabular}


Table A2. Concentrations of Phycocyanin (PC) and Chlorophyll-a (Chl-a) in reservoirs during sampling year.

\begin{tabular}{|c|c|c|c|c|c|}
\hline Reservoir and Year & $\mathrm{PC}(\mu \mathrm{g} / \mathrm{L})$ & Chl $a(\mu \mathrm{g} / \mathrm{L})$ & Reservoir and Year & $\mathrm{PC}(\mu \mathrm{g} / \mathrm{L})$ & Chl $a(\mu \mathrm{g} / \mathrm{L})$ \\
\hline Alarcon 2020 & 5.30 & 1.75 & Las Torcas 2017 & 2.98 & 1.72 \\
\hline Alarcon 2020 & 5.60 & 1.80 & Lechago 2019 & 4.30 & 3.01 \\
\hline Alarcon 2020 & 3.75 & 1.94 & Mansilla 2016 & 1.54 & 2.37 \\
\hline Alarcon 2020 & 4.75 & 1.80 & Mansilla 2017 & 1.61 & 2.96 \\
\hline Alarcon 2020 & 5.77 & 1.80 & Mezalocha 2017 & 34.08 & 7.65 \\
\hline Alarcon 2020 & 5.97 & 1.10 & Mezalocha 2018 & 5.96 & 2.62 \\
\hline Albufera 2020 & 188.14 & 30.14 & Moneva 2019 & 6.89 & 11.86 \\
\hline Albufera 2020 & 269.55 & 81.34 & Monteagudo 2018 & 8.70 & 1.59 \\
\hline Albufera 2020 & 329.05 & 91.92 & Oliana 2017 & 1.28 & 3.38 \\
\hline Albufera 2020 & 364.70 & 90.93 & Oliana 2019 & 2.76 & 6.50 \\
\hline Alloz 2017 & 3.10 & 1.34 & Oliana 2019 & 9.04 & 2.58 \\
\hline Barasona 2018 & 2.57 & 1.67 & Regajo 2017 & 11.14 & 8.97 \\
\hline Bellus 2017 & 185.43 & 61.39 & Regajo 2018 & 4.71 & 5.57 \\
\hline Bellus 2018 & 307.93 & 49.09 & Regajo 2018 & 4.94 & 4.58 \\
\hline Bellus 2018 & 318.50 & 51.59 & Regajo 2018 & 6.23 & 4.63 \\
\hline Bellus 2018 & 307.72 & 41.54 & Rialb 2018 & 5.19 & 2.89 \\
\hline Bellus 2020 & 63.15 & 24.59 & Rialb 2018 & 17.18 & 20.07 \\
\hline Bellus 2020 & 70.67 & 25.83 & Rialb 2019 & 5.38 & 4.29 \\
\hline Bellus 2020 & 129.52 & 30.06 & Ribarroja 2017 & 0.64 & 13.17 \\
\hline Bellus 2021 & 125.61 & 29.95 & Santolea 2016 & 4.01 & 1.11 \\
\hline Bellus 2021 & 145.27 & 29.87 & Sitjar 2017 & 3.49 & 0.61 \\
\hline Benageber 2020 & 8.68 & 2.50 & Sitjar 2017 & 3.71 & 0.72 \\
\hline Benageber 2017 & 9.06 & 5.77 & Sobron 2017 & 15.69 & 6.89 \\
\hline Benageber 2017 & 10.53 & 5.47 & Sobron 2019 & 11.60 & 10.31 \\
\hline Benageber 2018 & 8.01 & 4.91 & La Sotonera 2016 & 2.99 & 0.68 \\
\hline Benageber 2018 & 7.26 & 4.85 & La Sotonera 2016 & 1.29 & 2.25 \\
\hline Benageber 2018 & 8.19 & 4.91 & La Sotonera 2016 & 1.58 & 2.33 \\
\hline Benageber 2020 & 7,05 & 2.12 & La Sotonera 2018 & 15.52 & 3.44 \\
\hline Benageber 2020 & 8.80 & 2.44 & La Sotonera 2019 & 7.33 & 2.51 \\
\hline Benageber 2020 & 10.53 & 2.96 & Terradets 2018 & 24.76 & 1.16 \\
\hline Benageber 2020 & 7.37 & 2.38 & Tous 2017 & 1.70 & 1.85 \\
\hline Benageber 2020 & 8.73 & 2.68 & Tous 2017 & 4.01 & 0.69 \\
\hline Beniarres 2017 & 21.70 & 8.50 & Tous 2017 & 4.61 & 0.64 \\
\hline Beniarres 2017 & 19.02 & 17.17 & Urrunaga 2018 & 16.79 & 3.21 \\
\hline Canelles 2016 & 0.84 & 1.16 & Utchesa-Seca 2019 & 16.08 & 9.91 \\
\hline Canelles 2016 & 1.62 & 2.86 & Valdecañas 2020 & 22.70 & 1.78 \\
\hline Canelles 2020 & 1.93 & 1.41 & Valdecañas 2020 & 22.54 & 1.48 \\
\hline Cazalegas 2020 & 230.98 & 6.93 & Yesa 2017 & 2.23 & 3.46 \\
\hline Contreras 2018 & 8.37 & 2.46 & & & \\
\hline $\begin{array}{c}\text { Cueva Foradada } \\
2017\end{array}$ & 3.70 & 3.43 & & & \\
\hline $\begin{array}{c}\text { Cueva Foradada } \\
2018\end{array}$ & 13.23 & 14.22 & & & \\
\hline Ebro 2019 & 4.38 & 2.34 & & & \\
\hline $\begin{array}{c}\text { Estanca de Alcañiz } \\
2018\end{array}$ & 11.43 & 3.24 & & & \\
\hline Eugui 2017 & 2.93 & 5.95 & & & \\
\hline Flix 2018 & 14.29 & 2.28 & & & \\
\hline Galipuen 2019 & 27.28 & 3.41 & & & \\
\hline Itoiz 2017 & 2.36 & 2.52 & & & \\
\hline La Loteta 2019 & 9.10 & 1.83 & & & \\
\hline La Peña 2017 & 4.21 & 1.77 & & & \\
\hline La Tranquera 2016 & 10.94 & 5.95 & & & \\
\hline La Tranquera 2017 & 12.04 & 8.45 & & & \\
\hline La Tranquera 2018 & 17.35 & 11.75 & & & \\
\hline
\end{tabular}




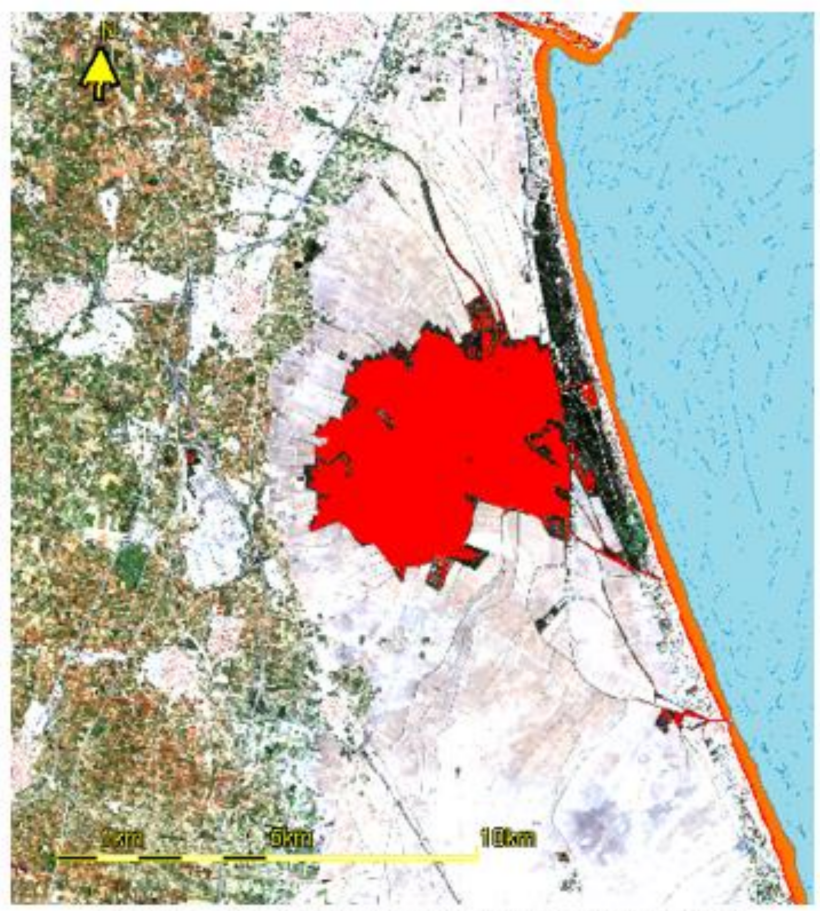

Albufera of Valencia lagoon (Jucar), 11 May 2019.

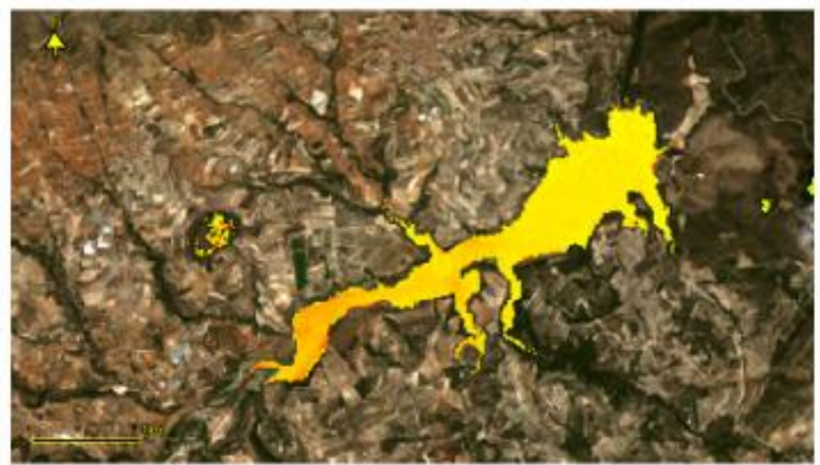

Beniarres (Jucar), 11 July 2017.

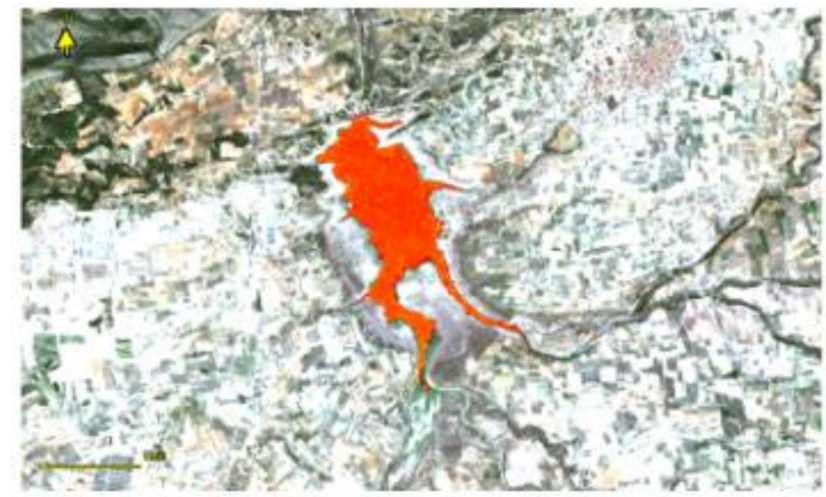

Bellus (Jucar), 25 June 2018.

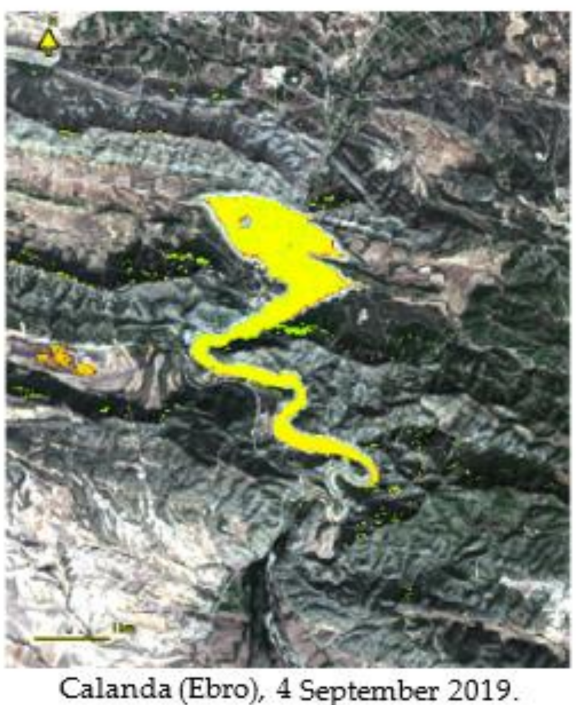

Calanda (Ebro), 4 September 2019.

PC

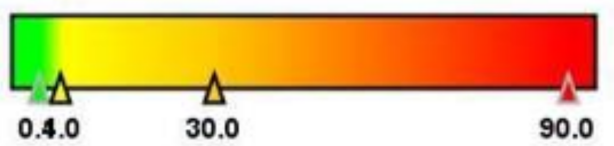

Figure A1. Thematic maps of PC $\left(\mu \mathrm{g} \mathrm{L}^{-1}\right)$ in some reservoirs, showing the alert level in a color scale according to Table 3. For each site, the date of the image and the watersheds are indicated. 


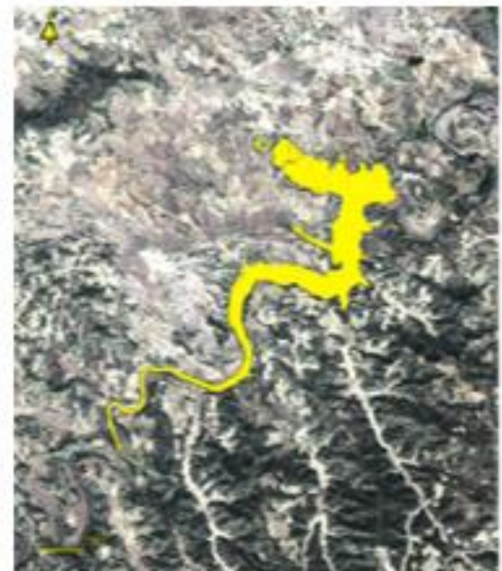

Caspe (Ebro), 4 September 2019.

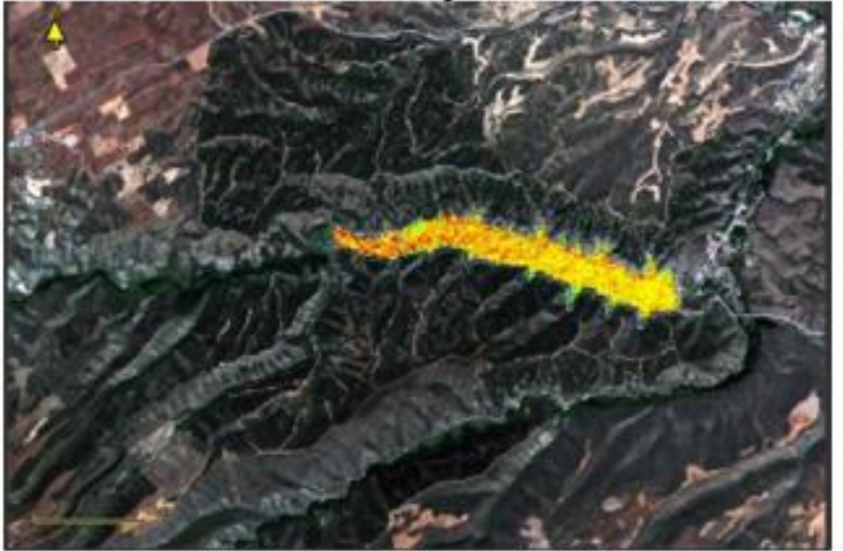

El Val (Ebro), 4 September 2019.

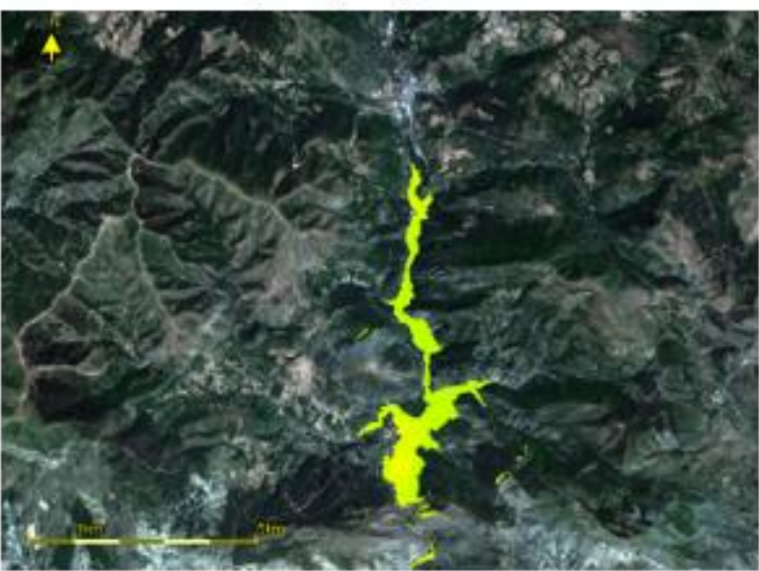

Escales (Ebro), 4 September 2019.
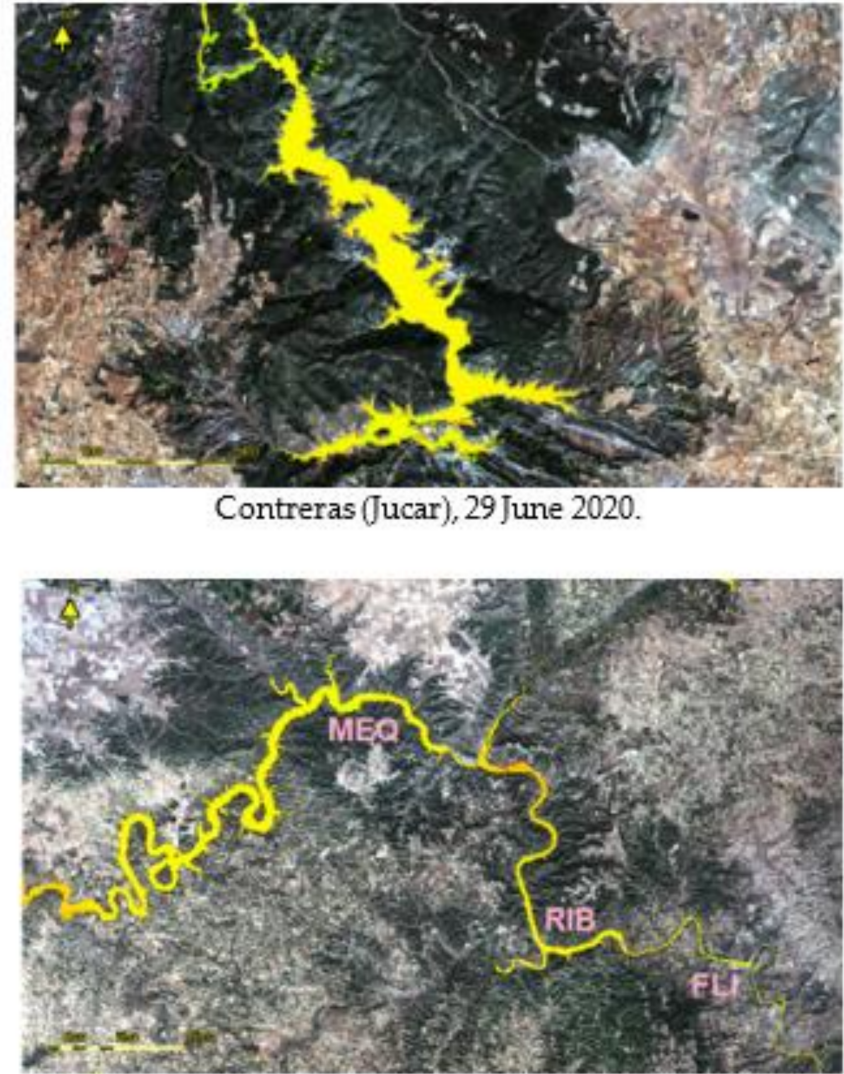

Mequinenza (MEQ), Ribarroja (RIB) and Flix (FLI) (Ebro), 5 May 2019

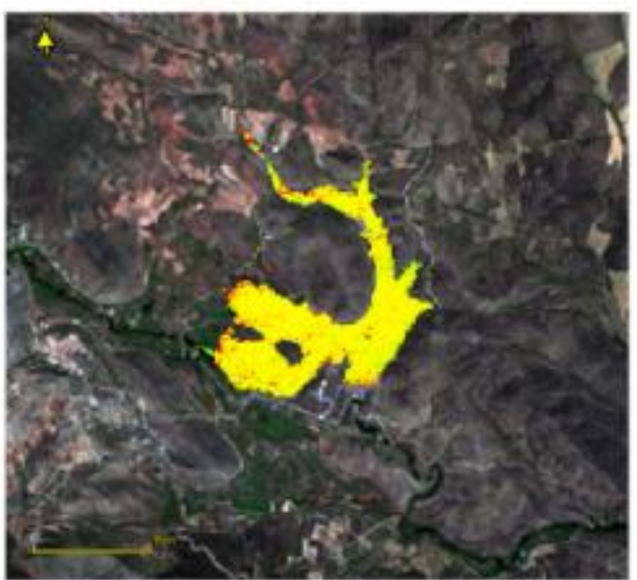

Maidevera (Ebro), 4 September 2019.

PC

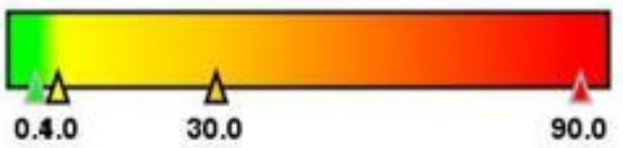

Figure A2. Thematic maps of PC $\left(\mu \mathrm{g} \mathrm{L}^{-1}\right)$ in some reservoirs, showing the alert level in a color scale according to Table 3. For each site, the date of the image and the watersheds are indicated. 


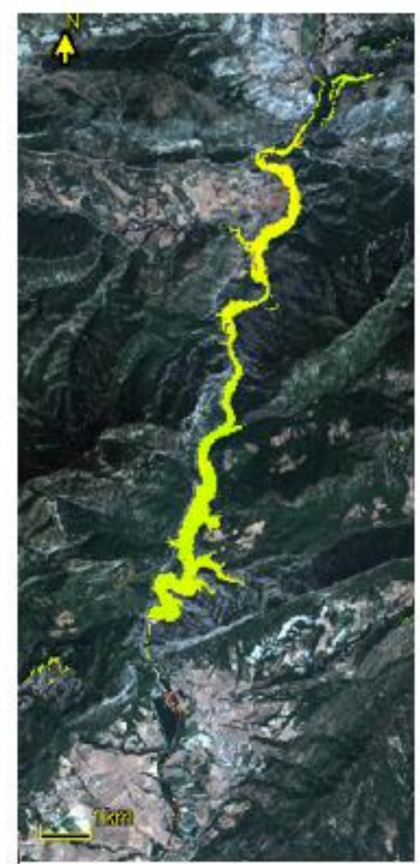

Oliana (Ebro), 31 May 2019.

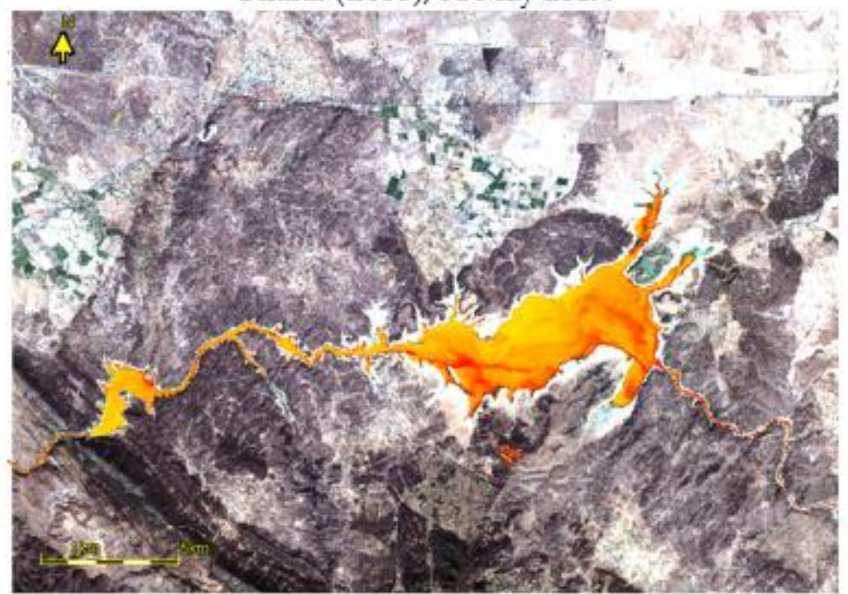

Valdecañas (Tagus), 9 September 2019.

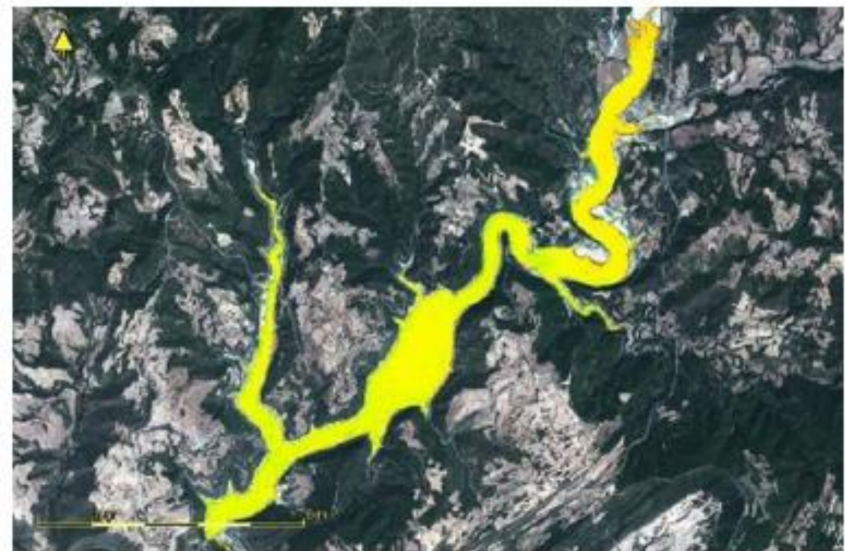

Rialb (Ebro), 31 May 2019.

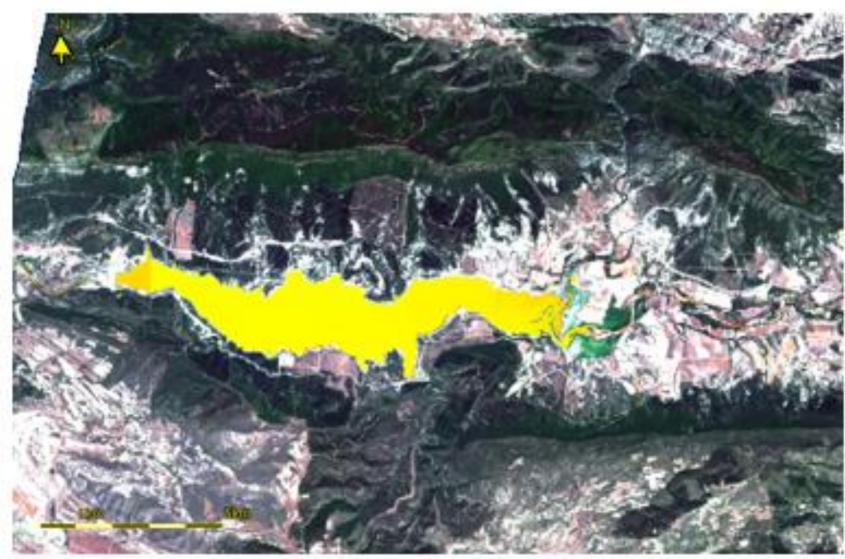

Yesa (Ebro), 4 September 2019.

PC

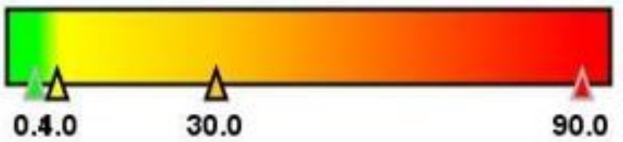

Figure A3. Thematic maps of PC $\left(\mu \mathrm{g} \mathrm{L}^{-1}\right)$ in some reservoirs, showing the alert level in a color scale according to Table 3. For each site, the date of the image and the watersheds are indicated.

\section{References}

1. Soria, J.M.; Montagud, D.; Sòria-Perpinyà, X.; Sendra, M.D.; Vicente, E. Phytoplankton Reservoir Trophic Index (PRTI): A new tool for ecological quality studies. Inland Waters 2019, 9, 301-308. [CrossRef]

2. Hallegraeff, G.; Anderson, D.M.; Hole, W.; Cembella, A. Harmful algal blooms: A global overview. In Manual on Harmful Marine Microalgae; UNESCO: Paris, France, 2003; Volume 33, pp. 1-22.

3. World Health Organization (WHO). Guidelines for Drinking-Water Quality, 4th ed.; World Health Organization: Ginebra, Switzerland, 2011; p. 636.

4. Lehner, B.; Döll, P.; Alcamo, J.; Henrichs, T.; Kaspar, F. Estimating the Impact of Global Change on Flood and Drought Risks in Europe: A Continental, Integrated Analysis. Clim. Chang. 2006, 75, 273-299. [CrossRef]

5. European Commision. Water Framework Directive. Off. J. Ref. 2000, 327, 1-73. 
6. Castenholz, R.W. General characteristics of the cyanobacteria. In Bergey's Manual of Systematics of Archaea and Bacteria; Wyley: Hoboken, NJ, USA, 2015; pp. 1-23. [CrossRef]

7. Chorus, I.; Welker, M. (Eds.) Toxic Cyanobacteria in Water, 2nd ed.; CRC Press: Boca Raton, FL, USA; Geneva, Switzerland, 2021; p. 859.

8. Huertas, I.E.; Rouco, M.; López-Rodas, V.; Costas, E. Warming will affect phytoplankton differently: Evidence through a mechanistic approach. Proc. R. Soc. B: Boil. Sci. 2011, 278, 3534-3543. [CrossRef] [PubMed]

9. Whitton, B.A.; Potts, M. Introduction to the Cyanobacteria. In Ecology of Cyanobacteria II; Springer: Dordrecht, Germany, 2012; pp. 1-13.

10. O'Neil, J.; Davis, T.; Burford, M.; Gobler, C. The rise of harmful cyanobacteria blooms: The potential roles of eutrophication and climate change. Harmful Algae 2012, 14, 313-334. [CrossRef]

11. Kähler, P.; Koeve, W. Marine dissolved organic matter: Can its C:N ratio explain carbon overconsumption? Deep. Sea Res. Part I: Oceanogr. Res. Pap. 2001, 48, 49-62. [CrossRef]

12. Hamilton, T.L.; Corman, J.R.; Havig, J.R. Carbon and nitrogen recycling during cyanoHABs in dreissenid-invaded and noninvaded US midwestern lakes and reservoirs. Hydrobiologia 2019, 847, 939-965. [CrossRef]

13. Carmichael, W.W. The Toxins of Cyanobacteria. Sci. Am. 1994, 270, 78-86. [CrossRef]

14. Randolph, K.; Wilson, J.; Tedesco, L.; Li, L.; Pascual, D.L.; Soyeux, E. Hyperspectral remote sensing of cyanobacteria in turbid productive water using optically active pigments, chlorophyll a and phycocyanin. Remote. Sens. Environ. 2008, 112, 4009-4019. [CrossRef]

15. Zanchett, G.; Oliveira-Filho, E.C. Cyanobacteria and Cyanotoxins: From Impacts on Aquatic Ecosystems and Human Health to Anticarcinogenic Effects. Toxins 2013, 5, 1896-1917. [CrossRef]

16. Glazer, A.N. Light guides. Directional energy transfer in a photosynthetic antenna. J. Biol. Chem. 1989, 264, 1-4. [CrossRef]

17. Glazer, A.N. Phycobilisome a macromolecular complex optimized for light energy transfer. Biochim. Biophys. Acta Rev. Bioenerg. 1984, 768, 29-51. [CrossRef]

18. Brient, L.; Lengronne, M.; Bertrand, E.; Rolland, D.; Sipel, A.; Steinmann, D.; Baudin, I.; Legeas, M.; Le Rouzic, B.; Bormans, M. A phycocyanin probe as a tool for monitoring cyanobacteria in freshwater bodies. J. Environ. Monit. 2008, 10, 248-255. [CrossRef]

19. Damar, A.; Colijn, F.; Hesse, K.-J.; Kurniawan, F. Coastal Phytoplankton Pigments Composition in Three Tropical Estuaries of Indonesia. J. Mar. Sci. Eng. 2020, 8, 311. [CrossRef]

20. Gomarasca, M.A.; Giardino, C.; Bresciani, M.; De Carolis, G.; Sandu, C.; Tornato, A.; Tonolo, F. Copernicus Sentinel missions for water resources. In Proceedings of the 6th International Conference on Space Science and Communication, Kebangsaan, Malaysia, 28-30 June 2019.

21. European Space Agency (ESA). Sentinel-2 Spectral Response Functions. 2017. Available online: https://sentinel.esa.int/web/ sentinel/user-guides/sentinel-2-msi/document-library/- / asset_publisher/Wk0TKajiISaR/content/sentinel-2a-spectralresponses (accessed on 10 June 2021).

22. Shoaf, W.T.; Lium, B.W. Improved extraction of chlorophyll a and b from algae using dimethyl sulfoxide. Limnol. Oceanogr. 1976, 21, 926-928. [CrossRef]

23. Jeffrey, S.T.; Humphrey, G.F. New spectrophotometric equations for determining chlorophylls a, b, c1 and c2 in higher plants, algae and natural phytoplankton. Biochem. Physiol. Pflanz. 1975, 167, 191-194. [CrossRef]

24. Radin, C.; Sòria-Perpinyà, X.; Delegido, J. Multitemporal water quality study in Sitjar (Castelló, Spain) reservoir using Sentinel-2 images. Rev. Teledetec. 2020, 56, 117-130. [CrossRef]

25. Toming, K.; Kutser, T.; Laas, A.; Sepp, M.; Paavel, B.; Nõges, T. First Experiences in Mapping Lake Water Quality Parameters with Sentinel-2 MSI Imagery. Remote. Sens. 2016, 8, 640. [CrossRef]

26. Beck, R.; Xu, M.; Zhan, S.; Liu, H.; Johansen, R.A.; Tong, S.; Yang, B.; Shu, S.; Wu, Q.; Wang, S.; et al. Comparison of Satellite Reflectance Algorithms for Estimating Phycocyanin Values and Cyanobacterial Total Biovolume in a Temperate Reservoir Using Coincident Hyperspectral Aircraft Imagery and Dense Coincident Surface Observations. Remote Sens. 2017, 9, 538. [CrossRef]

27. Sòria-Perpinyà, X.; Vicente, E.; Urrego, P.; Pereira-Sandoval, M.; Ruíz-Verdú, A.; Delegido, J.; Soria, J.; Moreno, J. Remote sensing of cyanobacterial blooms in a hypertrophic lagoon (Albufera of València, Eastern Iberian Peninsula) using multitemporal Sentinel-2 images. Sci. Total Environ. 2020, 698, 134305. [CrossRef]

28. Kwon, Y.S.; Pyo, J.; Duan, H.; Cho, K.H.; Park, Y. Drone-based hyperspectral remote sensing of cyanobacteria using vertical cumulative pigment concentration in a deep reservoir. Remote Sens. Environ. 2020, 236, 111517. [CrossRef]

29. Liu, G.; Simis, S.G.H.; Li, L.; Wang, Q.; Li, Y.; Song, K.; Lyu, H.; Zheng, Z.; Shi, K. A Four-Band Semi-Analytical Model for Estimating Phycocyanin in Inland Waters From Simulated MERIS and OLCI Data. IEEE Trans. Geosci. Remote Sens. 2017, 56, 1374-1385. [CrossRef]

30. Chorus, I.; Bartram, J. Toxic Cyanobacteria in Water. A Guide to their Public Health Consequences, Monitoring and Management; E\&FN Spon on behalf of the World Health Organization; Chorus, I., Welker, M., Eds.; CRC Press: London, UK, 1999; pp. 1-416. [CrossRef]

31. Ruiz-Verdú, A.; Simis, S.; de Hoyos, C.; Gons, H.J.; Peña-Martínez, R. An evaluation of algorithms for the remote sensing of cyanobacterial biomass. Remote Sens. Environ. 2008, 112, 3996-4008. [CrossRef] 
32. Sòria-Perpinyà, X.; Vicente, E.; Urrego, P.; Pereira-Sandoval, M.; Tenjo, C.; Ruíz-Verdú, A.; Delegido, J.; Soria, J.; Peña, R.; Moreno, J. Validation of Water Quality Monitoring Algorithms for Sentinel-2 and Sentinel-3 in Mediterranean Inland Waters with In Situ Reflectance Data. Water 2021, 13, 686. [CrossRef]

33. Viso-Vázquez, M.; Acuña-Alonso, C.; Rodríguez, J.; Álvarez, X. Remote Detection of Cyanobacterial Blooms and Chlorophyll-a Analysis in a Eutrophic Reservoir Using Sentinel-2. Sustainability 2021, 13, 8570. [CrossRef]

34. Paerl, H.W.; Xu, H.; McCarthy, M.J.; Zhu, G.; Qin, B.; Li, Y.; Gardner, W.S. Controlling harmful cyanobacterial blooms in a hyper-eutrophic lake (Lake Taihu, China): The need for a dual nutrient (N \& P) management strategy. Water Res. 2011, 45, 1973-1983. [CrossRef]

35. Kühl, M.; Fenchel, T. Bio-optical Characteristics and the Vertical Distribution of Photosynthetic Pigments and Photosynthesis in an Artificial Cyanobacterial Mat. Microb. Ecol. 2000, 40, 94-103. [CrossRef] [PubMed]

36. Hoyos, C.D.; Negro, A.I.; Aldasoro-Martín, J.J. Cyanobacteria distribution and abundance in the Spanish water reservoirs during thermal stratification. Limnetica 2004, 23, 119-132.

37. Navarro, E.; Caputo, L.; Marcé, R.; Carol, J.; Benejam, L.; García-Berthou, E.; Armengol, J. Ecological classification of a set of Mediterranean reservoirs applying the EU Water Framework Directive: A reasonable compromise between science and management. Lake Reserv. Manag. 2009, 25, 364-376. [CrossRef]

38. Durall, C.; Lindblad, P. Mechanisms of carbon fixation and engineering for increased carbon fixation in cyanobacteria. Algal Res. 2015, 11, 263-270. [CrossRef]

39. Izydorczyk, K.; Tarczynska, M.; Jurczak, T.; Mrowczynski, J.; Zalewski, M. Measurement of phycocyanin fluorescenceas an online early warning system for cyanobacteria in reservoir intake water. Environ. Toxicol. 2005, 20, 425-430. [CrossRef]

40. Ahn, C.-Y.; Joung, S.-H.; Yoon, S.-K.; Oh, H.-M. Alternative alert system for cyanobacterial bloom, using phycocyanin as a level determinant. J. Microbiol. 2007, 45, 98-104.

41. Li, L.; Sengpiel, R.E.; Pascual, D.L.; Tedesco, L.P.; Wilson, J.S.; Soyeux, E. Using hyperspectral remote sensing to estimate chlorophyll-a and phycocyanin in a mesotrophic reservoir. Int. J. Remote Sens. 2010, 31, 4147-4162. [CrossRef]

42. Ogashawara, I. The Use of Sentinel-3 Imagery to Monitor Cyanobacterial Blooms. Environments 2019, 6, 60. [CrossRef] 